The University of San Francisco

USF Scholarship: a digital repository @ Gleeson Library |

Geschke Center

Economics

College of Arts and Sciences

2013

\title{
Does International Child Sponsorship Work? A Six-Country Study of Impacts on Adult Life Outcomes
}

Bruce Wydick

University of San Francisco, wydick@lucas.usfca.edu

Paul Glewwe

Laine Rutledge

Follow this and additional works at: http://repository.usfca.edu/econ

Part of the Economics Commons

\section{Recommended Citation}

Bruce Wydick, Paul Glewwe, and Laine Rutledge. Does International Child Sponsorship Work? A Six-Country Study of Impacts on Adult Life Outcomes. Journal of Political Economy, Vol. 121, No. 2 (April 2013), pp. 393-436. DOI: 10.1086/670138

This Article is brought to you for free and open access by the College of Arts and Sciences at USF Scholarship: a digital repository @ Gleeson Library | Geschke Center. It has been accepted for inclusion in Economics by an authorized administrator of USF Scholarship: a digital repository @ Gleeson Library | Geschke Center. For more information, please contact repository@usfca.edu. 


\title{
Does International Child Sponsorship Work? A Six-Country Study of Impacts on Adult Life Outcomes
}

\section{Bruce Wydick}

University of San Francisco

\section{Paul Glewwe}

University of Minnesota

\section{Laine Rutledge}

University of Washington

\begin{abstract}
Child sponsorship is a leading form of direct aid from wealthy country households to children in developing countries. Over 9 million children are supported through international sponsorship organizations. Using data from six countries, we estimate impacts on several outcomes from sponsorship through Compassion International, a leading child sponsorship organization. To identify program effects, we utilize an ageeligibility rule implemented when programs began in new villages. We find large, statistically significant impacts on years of schooling; primary, secondary, and tertiary school completion; and the probability and quality of employment. Early evidence suggests that these impacts are due, in part, to increases in children's aspirations.
\end{abstract}

\section{Introduction}

For millions of households in wealthy countries, international child sponsorship represents the most intimate and direct form of involvement with

We would like to thank Wess Stafford, Joel Vanderhart, Scott Todd, Alistair Sim, Herbert Turyatunga, Jose-Ernesto Mazariegos, Ester Battz, Noel Pabiona, Rowena Campos, Sofia

[Journal of Political Economy, 2013, vol. 121, no. 2]

(C) 2013 by The University of Chicago. All rights reserved. 0022-3808/2013/12102-0002\$10.00 
the poor in developing countries. Sponsors typically give $\$ 25-\$ 40$ per month to supplement an impoverished child's education and health expenses or to support programs in which the child participates. We estimate that currently private financial flows to internationally sponsored children exceed US\$3 billion annually, yet no published research exists that has gauged these programs' impacts on the life outcomes of sponsored children.

This paper examines whether children sponsored through Compassion International, a leading child sponsorship organization currently serving 1.3 million children in 26 countries, have improved life outcomes when they are adults. Data were collected on the life outcomes of 10,144 individuals over 2 years from six developing countries that are representative of the Compassion program's work worldwide: Bolivia, Guatemala, India, Kenya, the Philippines, and Uganda.

Identification of the program's impacts rests on three eligibility rules that Compassion used from 1980 to 1992, when those in our study were sponsored. These rules limited the number of children per household that could be sponsored, required sponsored children to be within walking distance of a project, and stipulated that only children below a given age were eligible for the program. Using several estimation strategies that harness these eligibility rules to construct counterfactuals for estimating causal effects, we find that the Compassion sponsorship program significantly increased total years of schooling and completion rates across all levels of schooling. Impacts are especially large for secondary school completion, which increased by 12-18 percentage points over an average baseline of 44.5 percent. Education impacts are particularly strong in the two African countries. We also find positive and significant impacts on the probability of adult employment and movement into white-collar jobs.

Florance, Catherine Mbotela, Sam Wambugu, Boris Zegarra, Marcela Bakir, and other local Compassion staff and enumerators in Bolivia, Guatemala, India, Kenya, the Philippines, and Uganda for logistical help and support in carrying out our field research. Thanks to graduate students Joanna Chu, Ben Bottorff, Jennifer Meredith, Phillip Ross, Herman Ramirez, Mario Javier Carrillo, and Teddi Auker for outstanding work in the field. We also appreciate support and helpful comments from Christian Ahlin, Chris Barrett, Jere Behrman, Michael Carter, Alessandra Cassar, Pascaline Dupas, Giacomo De Giorgi, Alain de Janvry, Fred Finan, Pauline Grosjean, Phil Keefer, David Levine, Jeremy Magruder, David McKenzie, Craig McIntosh, Ted Miguel, Douglas Miller, Jeff Nugent, Jon Robinson, Elizabeth Sadoulet, John Strauss, and seminar participants at the University of California, Berkeley, Stanford University, the World Bank, the University of Southern California, the University of California, Davis, the Georgia Institute of Technology, the 2010 and 2011 Pacific Conferences for Development Economics, and the Behavior and the Escape from Persistent Poverty conference at Cornell University. We thank the anonymous referee of this Journal and especially editor Derek Neal for detailed and helpful comments on the original draft. We are grateful to BASIS/US Agency for International Development for substantial funding for this project, to two generous South Korean donors, and to the University of San Francisco's graduate program in International and Development Economics. 
In some respects, Compassion projects are similar to many government and international donor programs that promote education. Sponsors pay for children's school tuition and uniforms, several nutritious meals per week, health care, and tutoring. What distinguishes Compassion projects from most government and international donor programs, and from some other child sponsorship programs, is that children spend at least 8 hours per week in an intensive after-school program that emphasizes their spiritual, physical, and socioemotional development. In the sample, the average duration of sponsorship was 9.3 years, so that by the end of their childhood, sponsored children have participated in about 4,000 hours of Compassion programming, including extra activities such as retreats and camps. A primary objective of this extended contact is to raise the child's self-esteem, aspirations, and self-expectations.

Recent work in economics suggests that internal constraints that reflect low aspirations and reference points may lead to poverty traps (Ray 2006; Dalton, Ghosal, and Mani 2010; Bernard, Dercon, and Taffesse 2011). After reporting program impacts on adult life outcomes, we present a short summary of evidence from three follow-up studies that collected data and carried out other research among 1,380 currently sponsored Compassion children in Bolivia, Kenya, and Indonesia. These studies find that sponsored children exhibit significantly higher levels of selfesteem, aspirations, and self-expectations and lower levels of hopelessness. While more work is needed to establish a causal link between aspirations during youth and adult life outcomes, a clearer understanding of this relationship may have important implications for the way in which practitioners approach development work.

Two major empirical issues must be addressed to obtain unbiased estimates of the impact of this type of program. First, selection of children into a program may not be random; more needy children may have been chosen (as is directed in the Compassion operations manual), but it is also possible that parents chose the children who they thought were most likely to succeed. Second, program impacts may spill over onto siblings or nontreated peers in a treated village.

This study uses three program eligibility rules to address these two estimation issues. As Compassion established new projects from 1980 to 1992 in each of the six countries, an age-eligibility rule stipulated that only children 12 years and younger (11 years and under in Uganda and Guatemala) at the time the project started were eligible for sponsorship. This arbitrary rule allows us to compare the adult life outcomes of formerly sponsored children relative to the life outcomes of their ineligible older siblings, who were age 13 or older when the program was started in their village. Moreover, to maximize the number of households benefiting from sponsorships, a second rule set an upper limit on the number of sponsored children per household; this number varied from one to 
three in the six countries. Finally, a third rule stipulated that, to be sponsored, a child had to reside within walking distance of the program center, which was usually interpreted as at most a 30-minute walk. In practice, this meant that only children residing within the village where the program was located were chosen for sponsorship. Children from neighboring villages were excluded.

We use the first two rules to address the issue of endogenous child selection. Specifically, we use a vector of dummy variables that indicate the age of an individual when the Compassion program was introduced into that person's village interacted with his or her sibling order relative to program rollout (oldest sibling 12 or younger when the program began, second-oldest sibling among those 12 or younger when the program began, etc.) as instruments to estimate the probability that an individual was a sponsored child. These instruments are strongly correlated with takeup since children meeting the age requirement were far more likely to be sponsored, and in practice the oldest age-eligible siblings were most likely to be sponsored. These instruments satisfy the exclusion restriction for instrumental variables because as Compassion programs were introduced in different years in different villages, the age of an individual at the time the program began in his or her village should not be related to his or her life outcomes except via the impact of being sponsored.

We use the third rule to address the issue of program spillovers; we collected data not only on sets of siblings from treated families but also on sets of siblings from a random sample of nontreated households in Compassion villages and from a random sample of households in neighboring villages where children could not be sponsored because of the walking distance rule. Using the identifying assumptions that program spillovers affect neither older age-ineligible children in treated villages nor any children in non-Compassion villages, we implement both ordinary least squares (OLS) and instrumental variable (IV) differencein-differences regressions that estimate direct effects on program participants and can also be used to calculate both intrahousehold and intravillage spillovers from the Compassion program.

These estimates yield large and statistically significant effects of child sponsorship on education, employment, and leadership outcomes. OLS and IV estimations, with and without the use of household fixed effects, find that child sponsorship resulted in 1.03-1.46 additional years of completed schooling for sponsored children over a baseline of 10.24 years for unsponsored children. ${ }^{1}$ Impacts on primary schooling range from 4.0 to 7.7 percentage points over an untreated baseline of 88.7 percent.

\footnotetext{
"Years of schooling" denotes highest grade attained. Grade repetition is common in many countries, so years of schooling can exceed grade attained; we have no data on repetition, so we cannot account for repeated grades.
} 
Impacts on secondary school completion are greater and highly significant, ranging from 11.6 to 16.5 percentage points over a baseline of 44.9 percent; accounting for marginally significant spillover effects pushes the figure somewhat higher, to $13.7-18.5$ percentage points. Tertiary education point estimates of impact are smaller, from 2.1 to 3.6 percentage points, but these are realized over a small baseline of 4.3 percent. Child sponsorship also appears to be a great "equalizer." Its impacts on the educational outcomes are larger in those countries with lower baseline education outcomes, the two African countries, while impacts in Latin America and Asia are smaller, although still statistically significant. Similarly, in countries where baseline schooling is higher for boys, child sponsorship tends to have a bigger impact on girls; where it is higher for girls, it has a bigger impact on boys.

OLS estimates also find positive impacts on the probability of salaried employment (5.1-6.3 percentage points, over a 35.7 percent baseline) and white-collar work (6.5-6.7 percentage points, over a baseline of 18.7 percent). There is also evidence, albeit mixed, of increases in community and church leadership. ${ }^{2}$

Our results do not necessarily apply to all child sponsorship programs. While some of the other major child sponsorship organizations, such as Children International, use sponsor funding for the nurturing and development of individual children, other large programs, such as those operated by World Vision, Plan USA, and Save the Children, use funding given in the name of a sponsored child more broadly to create villagelevel public goods. ${ }^{3}$ The less targeted nature of these programs renders potential impacts more diffuse and thus more difficult to assess.

The remainder of this paper is organized as follows. Section II reviews the most relevant previous studies. Section III explains the fieldwork and data collection. Section IV describes the estimation strategy, and Section V presents estimates of the program impacts. Section VI presents conclusions and briefly discusses potential causal mechanisms through the impact of the program on children's aspirations, summarizing results from three follow-up studies of currently sponsored children.

\section{Existing Research and Literature}

Given the number of individuals involved in child sponsorship relationships and the billions of dollars committed to them, it is surprising that

\footnotetext{
${ }^{2}$ Results on adult life outcomes such as age of marriage, fertility, remittances, dwelling quality, and durable good ownership are found in our longer working paper (Wydick, Glewwe, and Rutledge 2013).

${ }^{3}$ More recently, World Vision has begun to give priority to programs that emphasize the personal development of children, giving less priority to funding physical infrastructure projects.
} 
almost no research exists that evaluates the impacts of these programs. One exception is the study by Kremer, Moulin, and Namunyu (2003), who use a randomized experiment to analyze the impacts of a Dutch child sponsorship program that funded new classroom construction and provided students a $\$ 6$ uniform and $\$ 3.44$ worth of textbooks. They find that even these relatively low-cost interventions induced student beneficiaries to attend school a half year longer and to advance a third of a grade farther in formal education.

More generally, a growing literature attempts to find cost-effective ways to induce parents to invest more in their children's education. Researchers have studied many programs, including cash transfers, free meals, provision of school uniforms, deworming medicine, and free medical treatment.

Perhaps the best-known and most frequently evaluated intervention is the PROGRESA (later renamed Oportunidades) conditional cash transfer (CCT) program. Implemented in 1997 in poor regions of Mexico, Oportunidades provides cash incentives for mothers to increase their children's school attendance and obtain health care for younger children. It was initially implemented as a randomized trial to facilitate its evaluation by researchers. Impact evaluations have shown that Oportunidades led to higher school enrollment, lower grade repetition, lower dropout rates, and higher school reentry rates among dropouts (Behrman, Sengupta, and Todd 2005; World Bank 2009). Behrman, Parker, and Todd (2007) estimate that receiving Oportunidades cash transfers for 5.5 years increased grades completed by $0.8-1.0$ year. Schultz (2004) estimates that Oportunidades increased formal schooling by 0.66 year $(0.72$ for girls and 0.64 for boys). He also finds that Oportunidades raised enrollment by 3.4 percentage points, averaging over all children in grades $1-8$, with much larger impacts in later grades, not only for girls (14.8 percentage points) but also for boys (6.5 percentage points). Bobonis and Finan (2009) find that enrollment rates in Oportunidades communities increased by 5 percentage points, even among those ineligible for the program.

CCT programs have also had positive impacts on education in other countries. For example, Barrera-Osorio et al. (2008) implemented a randomized experiment to evaluate the Conditional Subsidies for School Attendance program in Bogota, Colombia, finding that school attendance increased by 2.8 percentage points on average.

Other programs have funded various school "inputs," such as free or subsidized school meals, uniforms, textbooks, school construction, and teachers. Several focus on nutrition or health. Drèze and Kingdon (2001) find that providing a midday meal in India raised girls' school attendance by 15 percentage points. Kremer and Vermeersch (2004) estimate that 
school attendance rose by 8.5 percentage points in Kenyan preschools that provided free meals, increasing attendance of current students and attracting new students who had never attended preschool. Handa and Peterman (2007) find that South African children's educational attainment is strongly affected by their nutritional status. Glewwe and Miguel (2008) review the impact of health and nutrition on education outcomes.

Many randomized studies of education interventions have been conducted in Kenya. Evans, Kremer, and Ngatia (2008) evaluate a program that selected Kenyan children by lottery to receive free school uniforms. They find that receiving a uniform reduced absenteeism by 39 percent and by 64 percent for poorer students. In the same area of Kenya, Miguel and Kremer (2004) implemented a randomized deworming intervention. This intervention not only decreased overall disease transmission but also reduced school absenteeism by 7 percentage points in the treatment schools. They also find positive spillover effects onto children who attended nearby schools that did not participate in the deworming program. In a follow-up study of former participants 10 years after the deworming experiment, Ozier (2011) finds increases in cognitive performance equal to $0.5-0.8$ year of schooling. A randomized trial that provided sixth-grade girls merit scholarships of about $\$ 20$ for school fees and school supplies increased student attendance by 5 percentage points; surprisingly, it increased both girls' and boys' test scores (Kremer, Miguel, and Thornton 2009). Another study in Kenya provided incentives to teachers to improve their teaching. Glewwe, Ilias, and Kremer (2010) carried out an experiment that provided valuable prizes to teachers on the basis of their students' test scores. Despite the incentives, teacher attendance did not improve; instead teachers held additional prep sessions prior to the exams on which the incentives were based, which led to only short-term increases in test scores.

Methodologically, the empirical strategy of this paper is similar to that of Duflo (2001) in that it uses the ages of former students and geographic placement of a schooling treatment as instruments to identify program impacts. Using a method similar to that of Pitt, Rosenzweig, and Gibbons (1993), Duflo examines the impact of Indonesia's rapid expansion of school construction from 1973 to 1979 . She uses an individual's exposure to the program, as measured by the number of schools built in his or her region of birth, along with age at the time of program implementation, to identify impacts on education and wages. She finds that each new school constructed per 1,000 children led to a 0.12-0.19 increase in years of schooling. This implies an average increase of 0.25-0.40 year per child beneficiary (about two schools were built per 1,000 children), which then resulted in a 3.0-5.4 percent increase in 
wages, suggesting an economic return to education of 6.8-10.6 percent. She also finds that those who benefited most were among the poorest.

\section{Counting the Sponsored, Program Background, and Fieldwork}

\section{A. Counting the Sponsored}

There have been no reliable figures on the number of internationally sponsored children worldwide; a preliminary task was to estimate this figure. Through Internet searches in multiple languages and contact with industry personnel across countries, we tallied 207 organizations that appear to represent nearly all children sponsored through such organizations worldwide. On the basis of the sponsorship figures claimed by these organizations, we estimate that there are currently 9.14 million internationally sponsored children in the world. ${ }^{4}$ Over 90 percent of this total are sponsored through the 10 largest sponsorship organizations. Table 1 contains basic information about these organizations, including years of operation, number of countries served, monthly sponsorship fees, and number of children sponsored. All are based in the United States and Europe, and two of the largest three are faith based, as are four of the largest 10.

The total flow of child sponsorship funds to developing countries is nontrivial; indeed it is similar to amounts given by the US government for international assistance. Assuming an average monthly contribution of $\$ 30$, funding for child sponsorship is about $\$ 3.29$ billion per year, excluding special gifts and travel to visit sponsored children. This is comparable to US Agency for International Development budgets of $\$ 8.72$ billion in 2012 for Global Health and Child Survival, \$2.92 billion for Development Assistance, and the $\$ 1.12$ billion earmarked for the Millennium Challenge Corporation (Office of Management and Budget 2012).

International child sponsorship programs arose because of their usefulness as a marketing tool for mobilizing resources in rich countries to reduce poverty in poor countries. As the marketers of these programs have recognized for decades, contact with an individual child creates a commitment device to help donors contribute a fraction of their monthly income to alleviating child poverty in developing countries via a relationship with a particular child living in poverty. In this way, international child sponsorship programs mobilize resources by drawing on the psy-

\footnotetext{
${ }^{4}$ Because the Internet is so vital today for fund-raising in the child sponsorship industry, e.g., posting pictures of children and providing other contact between potential sponsors and potentially sponsored children, we assumed that any such organization of significant scope must have an Internet presence. This assumption is the basis for our calculation of 9.14 million sponsored children. If there are child sponsorship programs that do not use the Internet, our 9.14 million figure would underestimate the actual number of children sponsored worldwide.
} 
TABLE 1

The 10 Leading International Child Sponsorship Programs

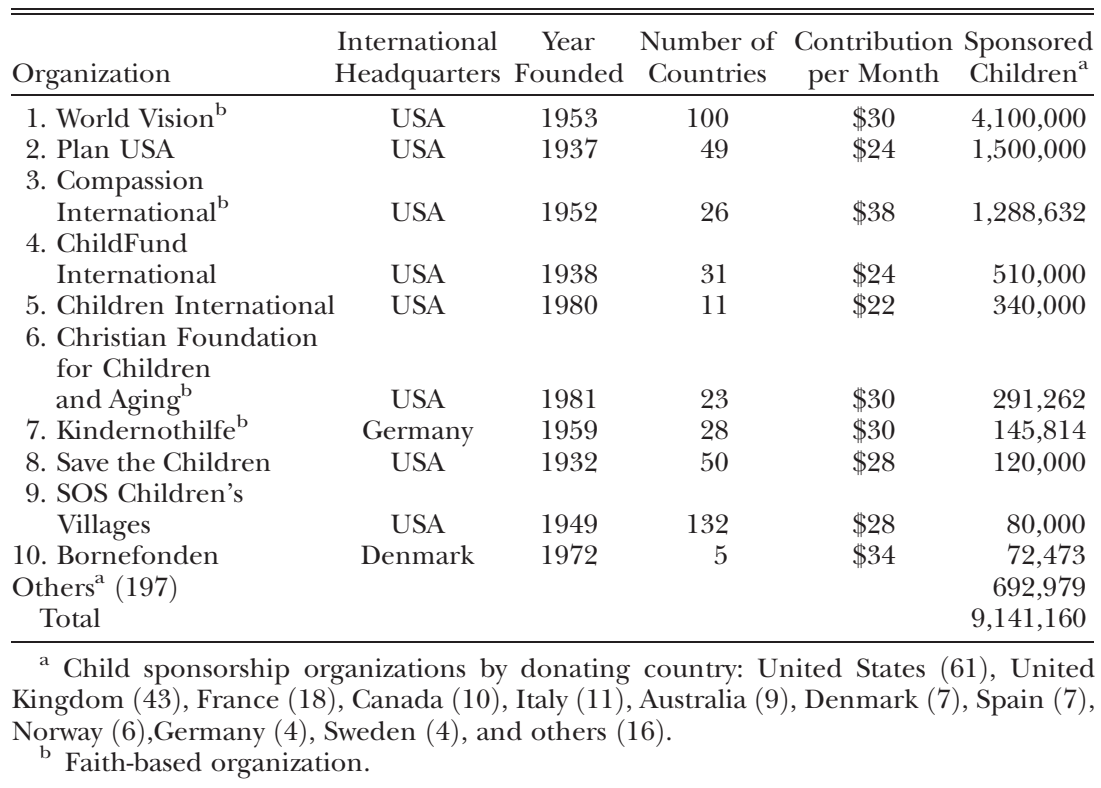

chological and moral instincts people possess to care for their own children. Even in difficult economic times, the commitment of donors to the well-being of "their child" is likely to exceed their commitment to a large, well-intentioned - yet relatively faceless - nonprofit organization. ${ }^{5}$ Thus even apart from issues of impact and cost-effectiveness, child sponsorship programs may be among the most effective methods for mobilizing resources to benefit children in developing countries.

\section{B. The Compassion Child Sponsorship Program}

The world's third-largest child sponsorship program is Compassion International, a large, faith-based, nonprofit organization whose stated goal is to "release children from spiritual, economic, social, and physical poverty." Compassion staffs its projects locally, and foreign employees are rare. The projects rely on volunteers from local churches and other organizations to carry out its programming. The benefits sponsored children receive vary somewhat by country and even within countries, and Compassion's approach has evolved over time. Table 2 summarizes, for each country in this study, the benefits the sponsored children received

\footnotetext{
${ }^{5}$ There is at least anecdotal evidence of this: During the first year of the 2008-9 recession, when giving to most US charities declined sharply, World Vision reported that the percentage of those who maintained their monthly financial commitment to sponsored children showed no sign of decline during that period (Kennedy 2009).
} 
TABLE 2

Compassion Program Benefits by Country

\begin{tabular}{lccccccc}
\hline \hline Country & Uniforms & Tutoring & $\begin{array}{c}\text { School } \\
\text { Materials }\end{array}$ & $\begin{array}{c}\text { Spiritual } \\
\text { Instruction }\end{array}$ & $\begin{array}{c}\text { Health } \\
\text { Care }\end{array}$ & $\begin{array}{c}\text { Gifts from } \\
\text { Sponsors }\end{array}$ & $\begin{array}{c}\text { Cash to } \\
\text { Family }\end{array}$ \\
\hline Uganda & Yes & Yes & Yes & Yes & Yes & Yes & No \\
Guatemala & Yes & Limited & Yes & Yes & Yes & Yes & No \\
Philippines & Limited & Limited & Yes & Yes & Yes & Yes & No \\
India & Yes & Yes & Yes & Yes & Yes & Yes & Yes \\
Kenya & Yes & Yes & Limited & Yes & Yes & Yes & No \\
Bolivia & Limited & Yes & Yes & Yes & Yes & Yes & Limited \\
\hline
\end{tabular}

while enrolled in the program. In Uganda and Kenya and in three of the projects in Bolivia, Compassion operated student centers where sponsored children gathered on Saturday or after school on weekdays. Students participated in structured programs at these centers, receiving academic tutoring, spiritual instruction, health care, nutritious meals, and school supplies. They also participated in a wide array of games and activities. In most of the projects with student centers, Compassion children also received school fee subsidies and school uniforms. Compassion typically sponsors children through secondary school, although a small number continue to the university level through its leadership development program.

In Guatemala and the Philippines, Compassion programs operated in (Protestant) Christian schools, where students would receive similar benefits, although tutoring was not generally an explicit component of sponsorship. In India and in one project in Bolivia, Compassion collaborated with government programs that gave parents direct cash payments conditional on the sponsored child's continuation in school. However, these programs differed from standard CCT programs in that children received most of the benefits provided by the other Compassion programs, as well as individual nurturing and care via Compassion's partnership with local Protestant churches.

All projects provided basic health care benefits. They included regular physical examinations administered by local nurses and doctors at Compassion schools and student centers. Also included was a form of catastrophic health insurance paid through a separate fund operated by Compassion's headquarters in Colorado. If a Compassion child had a serious illness or needed surgery, this fund covered the full cost of the procedure and hospitalization. In the rare cases in which children needed such care, this benefit was often reported by formerly sponsored children to be the greatest source of support offered by the program. Aside from this catastrophic insurance, however, all funds directed to children flow from their sponsors' regular monthly contributions. 
All children sponsored through Compassion write letters several times per year to their sponsor, and most receive correspondence from their sponsor (71.8 percent in our study). In addition, about once per year sponsors receive a picture of the child and updates from local Compassion staff on the child's progress in school. Most children (83.7 percent) also reported receiving birthday gifts from their sponsor. Sponsors can also travel on organized trips to visit their sponsored children and their families; while not uncommon, this was not the norm.

The survey included an open-ended question asking formerly sponsored children which component of the Compassion program had been most beneficial to them. The most common answer was educational support (38.5 percent). (Within this category, payment of school fees and tutoring were cited most often, and almost equally.) The second-most common response was spiritual and character development (29.4 percent), followed by economic aid ( 9.5 percent - a figure that was no higher in the two countries where parents received direct cash payments), health care benefits (2.8 percent), and gifts received from sponsors ( 0.8 percent).

In Compassion projects, selection of children for sponsorship is done locally. Compassion instructs its staff to work with local community members to select children using six criteria:

1. Sponsored children are to be from low-income families within walking distance of a project. The official selection criteria state, "When only a percentage of the children are sponsored from an institution, the school or parent committee should choose children among the neediest families for sponsorship."

2. Orphans, children living with a widowed parent or other family member, and refugees are given special priority.

3. The child cannot have been sponsored by another agency.

4. Children from both Christian and non-Christian families may participate equally, but all families must allow their children to participate in the program's Christian religious instruction.

5. Compassion sponsors a maximum of three children per family. Some countries set a lower limit (one or two per family).

6. Children older than 12 years cannot be sponsored. Children in kindergarten and in first, second, or third grade receive top priority; older children (still age 12 or under) receive lower priority.

The last guideline was intended to lengthen the number of years that a child can be sponsored and was fully operational after programs had operated for several years. However, when a program was first introduced into a village, parents tended to select older eligible children rather than younger eligible children. The mean length of sponsorship in our data is 9.3 years. 


\section{Survey and Fieldwork}

The survey work in the six countries of our main study took place from June 2008 to August 2010. Table 3 shows, for each country, a list of villages, rollout years for each village, sample sizes, and survey dates. Some projects started on a large scale, enrolling up to 100 children in the first year. Others started with fewer children, enrolling only 20-30 in the first year. For the larger projects, individuals were randomly selected to be surveyed from the first 2 or 3 years of enrollment lists. For smaller projects, data were collected from all children who were enrolled in the first 2 or 3 years. To avoid attrition bias, the sample includes both children who were sponsored for many years and children who dropped out relatively early.

In some cases the enrollment lists from which we sampled formerly sponsored children were in an electronic database at the country office. In others the only lists were hard copies of computer printouts kept on file at the project sites, which were found after extensive searches of file cabinets or basement boxes. Two of the 19 projects no longer sponsored children through Compassion.

TABLE 3

SURVEY INFORMATION By COUNTRY

\begin{tabular}{|c|c|c|c|c|}
\hline Country & $\begin{array}{c}\text { Treatment Villages } \\
\text { and Cities }\end{array}$ & $\begin{array}{c}\text { Nontreatment } \\
\text { Villages and Cities }\end{array}$ & $\begin{array}{l}\text { Sample } \\
\text { Size }\end{array}$ & $\begin{array}{l}\text { Time of } \\
\text { Survey }\end{array}$ \\
\hline Uganda & $\begin{array}{l}\text { Jinja (1980), }{ }^{\text {a }} \text { Bugiri } \\
\quad(1981), \text { Masaka (1989) }\end{array}$ & Kakooge, Bombo & 809 & $\begin{array}{l}\text { June-August } \\
2008\end{array}$ \\
\hline Guatemala & $\begin{array}{l}\text { San Pedro La Laguna } \\
\text { (1991), San Juan La } \\
\text { Laguna (1992), San } \\
\text { Pedro Necta (1992) }\end{array}$ & $\begin{array}{l}\text { San Pablo La Laguna, } \\
\text { Santiago } \\
\text { Chimaltenango }\end{array}$ & 1,762 & $\begin{array}{l}\text { May-July } \\
2009\end{array}$ \\
\hline Philippines & $\begin{array}{l}\text { Quezon City (1986), } \\
\text { Bacolod (1986) }\end{array}$ & Skybag, Handumanan & 1,428 & $\begin{array}{l}\text { November } \\
2009- \\
\text { February } \\
2010\end{array}$ \\
\hline India & $\begin{array}{l}\text { Tuticorn (1980), } \\
\text { Sawyerpuram (1980), } \\
\text { Bangalore (1986) }\end{array}$ & Eral, Bangalore & 1,622 & $\begin{array}{l}\text { March-April } \\
2010\end{array}$ \\
\hline Kenya & $\begin{array}{l}\text { Cianthia (1986), Cierria } \\
\text { (1986), Nderu (1990), } \\
\text { Thigio (1990) }\end{array}$ & $\begin{array}{l}\text { Riakingenyi, Kerwa, } \\
\text { Rusigeti }\end{array}$ & 3,056 & $\begin{array}{l}\text { April-June } \\
2010\end{array}$ \\
\hline Bolivia & $\begin{array}{l}\text { Chulla (1992), Los Olivios } \\
\text { (1990), Puntiti (1991), } \\
\text { Pongonhuyo (1980) }\end{array}$ & $\begin{array}{l}\text { Pairumani-Iscaypata, } \\
\text { Igrana }\end{array}$ & 1,467 & $\begin{array}{l}\text { June-August } \\
2010\end{array}$ \\
\hline Six countries & 19 Compassion programs & 13 nontreatment areas & 10,144 & $\begin{array}{l}\text { June } 2008- \\
\text { August } \\
2010\end{array}$ \\
\hline
\end{tabular}

\footnotetext{
${ }^{a}$ Year the program began.
} 
Local assistants were hired to locate the households of formerly sponsored individuals who were on the early enrollment lists. They were usually recommended by project staff and were known to be responsible, well-respected community members. They also had been raised in the village and so were knowledgeable about the community, but we eschewed hiring enumerators with formal connections with Compassion to avoid bias in responses. We located close to 99 percent of the targeted households in Uganda, Guatemala, and Kenya and about 90 percent in India and Bolivia. In the Philippines slightly less than 80 percent were located because of a high rate of household mobility following sponsorship. Overall, we located 93.5 percent of the families of the formerly sponsored children who were on the enrollment lists for the first 2-3 years the program operated in each village. Families who were not located had key family members who had passed away or had migrated to unknown areas of the country or to known areas but without specific details regarding their location.

In addition to these Compassion households, we surveyed 50-75 nonCompassion households in each Compassion village, conditional on the presence of an individual in the household being born in the 10 years before the Compassion project began operation. We also randomly sampled a similar number of households in neighboring villages without a Compassion program that were similar to the nearby Compassion villages. Households that did not participate in the program, from either Compassion or non-Compassion villages, were surveyed in order to check for intrahousehold and intravillage spillovers, as explained below in Section IV. The overall, six-country data set includes information on 1,860 formerly sponsored children, 3,704 of their unsponsored siblings, 2,136 individuals from nonparticipating families in villages where the Compassion program operated, and 2,444 individuals from similar, nearby villages without the Compassion program.

The samples of non-Compassion households, from both the Compassion and the non-Compassion villages, were randomly selected as follows. A starting point in the village was randomly chosen, and then every third household on the street was selected for possible inclusion in the survey. The household was briefly questioned to see whether any of its members met the sponsorship age criteria. When the end of the street or block was reached, the enumerator turned left and continued with every second or third household, then turned right and proceeded in this way, choosing new random points in the village on different days.

Table 4 shows summary statistics for the outcome variables and key control variables. The survey questionnaire we used had questions to collect basic information on adult life outcomes of both sponsored children and their siblings, as well as children in nonparticipating house- 
TABLE 4

Summary Statistics

\begin{tabular}{|c|c|c|c|c|c|c|c|}
\hline & Uganda & Guatemala & Philippines & India & Kenya & Bolivia & $\begin{array}{c}\text { All Six } \\
\text { Countries }\end{array}$ \\
\hline $\begin{array}{l}\text { Sponsored as a } \\
\text { child }\end{array}$ & $\begin{array}{l}.232 \\
(.423)\end{array}$ & $\begin{array}{l}.213 \\
(.409)\end{array}$ & $\begin{array}{l}.168 \\
(.374)\end{array}$ & $\begin{array}{l}.138 \\
(.345)\end{array}$ & $\begin{array}{l}.178 \\
(.383)\end{array}$ & $\begin{array}{l}.198 \\
(.398)\end{array}$ & $\begin{array}{l}.183 \\
(.387)\end{array}$ \\
\hline Years sponsored & $\begin{array}{l}11.325 \\
(3.067)\end{array}$ & $\begin{array}{c}6.717 \\
(2.467)\end{array}$ & $\begin{array}{c}7.469 \\
(4.629)\end{array}$ & $\begin{array}{l}11.065 \\
(3.230)\end{array}$ & $\begin{array}{l}10.207 \\
(3.332)\end{array}$ & $\begin{array}{c}9.510 \\
(3.747)\end{array}$ & $\begin{array}{c}9.287 \\
(3.790)\end{array}$ \\
\hline $\begin{array}{l}\text { Total years of } \\
\text { education }\end{array}$ & $\begin{array}{c}9.185 \\
(4.003)\end{array}$ & $\begin{array}{c}8.859 \\
(4.295)\end{array}$ & $\begin{array}{l}12.180 \\
(1.994)\end{array}$ & $\begin{array}{l}11.696 \\
(3.345)\end{array}$ & $\begin{array}{c}10.442 \\
(3.078)\end{array}$ & $\begin{array}{l}10.750 \\
(4.155)\end{array}$ & $\begin{array}{l}10.566 \\
(3.654)\end{array}$ \\
\hline $\begin{array}{c}\text { Completed } \\
\text { primary }\end{array}$ & $\begin{array}{l}.841 \\
(.366)\end{array}$ & $\begin{array}{l}.795 \\
(.404)\end{array}$ & $\begin{array}{l}.994 \\
(.080)\end{array}$ & $\begin{array}{l}.937 \\
(.244)\end{array}$ & $\begin{array}{l}.953 \\
(.211)\end{array}$ & $\begin{array}{l}.847 \\
(.360)\end{array}$ & $\begin{array}{l}.905 \\
(.293)\end{array}$ \\
\hline $\begin{array}{l}\text { Completed } \\
\text { secondary }\end{array}$ & $\begin{array}{l}.269 \\
(.444)\end{array}$ & $\begin{array}{l}.486 \\
(.500)\end{array}$ & $\begin{array}{l}.745 \\
(.436)\end{array}$ & $\begin{array}{c}.602 \\
(.490)\end{array}$ & $\begin{array}{l}.338 \\
(.473)\end{array}$ & $\begin{array}{l}.537 \\
(.499)\end{array}$ & $\begin{array}{l}.485 \\
(.500)\end{array}$ \\
\hline Completed tertiary & $\begin{array}{l}.077 \\
(.266)\end{array}$ & $\begin{array}{l}.022 \\
(.148)\end{array}$ & $\begin{array}{l}.019 \\
(.135)\end{array}$ & $\begin{array}{l}.047 \\
(.212)\end{array}$ & $\begin{array}{l}.040 \\
(.195)\end{array}$ & $\begin{array}{l}.117 \\
(.321)\end{array}$ & $\begin{array}{l}.049 \\
(.216)\end{array}$ \\
\hline Age & $\begin{array}{l}28.968 \\
(8.642)\end{array}$ & $\begin{array}{l}26.635 \\
(6.468)\end{array}$ & $\begin{array}{l}29.054 \\
(8.751)\end{array}$ & $\begin{array}{l}32.575 \\
(8.813)\end{array}$ & $\begin{array}{l}30.806 \\
(7.919)\end{array}$ & $\begin{array}{c}29.113 \\
(7.893)\end{array}$ & $\begin{array}{l}29.827 \\
(8.232)\end{array}$ \\
\hline Gender (female) & $\begin{array}{l}.476 \\
(.500)\end{array}$ & $\begin{array}{l}.511 \\
(.500)\end{array}$ & $\begin{array}{l}.502 \\
(.500)\end{array}$ & $\begin{array}{l}.500 \\
(.500)\end{array}$ & $\begin{array}{l}.515 \\
(.500)\end{array}$ & $\begin{array}{l}.501 \\
(.500)\end{array}$ & $\begin{array}{l}.505 \\
(.500)\end{array}$ \\
\hline $\begin{array}{l}\text { Number of } \\
\text { siblings }\end{array}$ & $\begin{array}{c}4.580 \\
(2.339)\end{array}$ & $\begin{array}{l}4.838 \\
(2.195)\end{array}$ & $\begin{array}{c}4.389 \\
(2.089)\end{array}$ & $\begin{array}{c}3.991 \\
(1.944)\end{array}$ & $\begin{array}{c}6.307 \\
(2.237)\end{array}$ & $\begin{array}{c}4.908 \\
(2.003)\end{array}$ & $\begin{array}{c}5.076 \\
(2.308)\end{array}$ \\
\hline $\begin{array}{l}\text { Mother's } \\
\text { education }\end{array}$ & $\begin{array}{c}5.385 \\
(3.778)\end{array}$ & $\begin{array}{c}2.105 \\
(2.909)\end{array}$ & $\begin{array}{c}9.682 \\
(3.120)\end{array}$ & $\begin{array}{c}6.982 \\
(3.645)\end{array}$ & $\begin{array}{c}3.862 \\
(4.116)\end{array}$ & $\begin{array}{c}2.783 \\
(3.059)\end{array}$ & $\begin{array}{c}4.853 \\
(4.338)\end{array}$ \\
\hline $\begin{array}{l}\text { Father's } \\
\text { education }\end{array}$ & $\begin{array}{c}7.024 \\
(4.044)\end{array}$ & $\begin{array}{c}3.496 \\
(3.645)\end{array}$ & $\begin{array}{l}10.032 \\
(3.203)\end{array}$ & $\begin{array}{c}7.629 \\
(3.635)\end{array}$ & $\begin{array}{c}5.538 \\
(4.318)\end{array}$ & $\begin{array}{c}4.727 \\
(3.381)\end{array}$ & $\begin{array}{c}6.166 \\
(4.310)\end{array}$ \\
\hline
\end{tabular}

Note.-Entries are means; standard deviations are in parentheses.

holds. These included questions on an individual's level of schooling, type of employment, and whether he or she held various leadership positions. The questionnaire was designed to ask each question sequentially across all siblings by age to avoid focusing on the sibling(s) who had been sponsored by Compassion. The questions were designed to be easily answered in order to obtain data on the basic life outcomes of adults that would be common knowledge among family members. We eschewed questions that asked for detailed data or for exact values of continuous variables since family members may not be able to provide such information. Many of the questions were obtained from the education modules in the World Bank's Living Standards Measurement Study surveys.

We interviewed all available family members jointly regarding the life outcomes of each formerly sponsored child and his or her siblings. Although, in most cases, several family members answered questions 
on sibling life outcomes, most of the information was collected from the principal respondent. The most common principal respondents were the parents of the sponsored child (36.6 percent) and the formerly sponsored child (35.8 percent), followed by siblings (22.4 percent) and other relatives (5.2 percent).

\section{Empirical Methodology}

We employ a variety of estimation techniques to identify the impact of the Compassion sponsorship program. Important to each approach is the program's 12 years and under eligibility rule. Figure 1 shows the probability that a child in a treated household was sponsored as a function of his or her age at the Compassion program introduction (ACI) into his or her village. On average over the bars in the figure, a child in a treated household who was between 0 and 12 years old when the program came to his or her village had a 458 probability of sponsorship; for a child who was 12-18, the probability was only.022. (A few 13-year-old children were sponsored because their photos had been taken and posted for sponsorship when of eligible age but a sponsor was not found until they were 13.)

Figures 2 and 3 illustrate differences between treated and nontreated households in years of completed schooling and the probability of completing secondary school, respectively, as a function of 2-year ACI categories (for visual smoothness). Both figures compare treated households to nontreated households in Compassion villages. In figure 2, for treated

\section{Probability of Sponsorship by ACI}

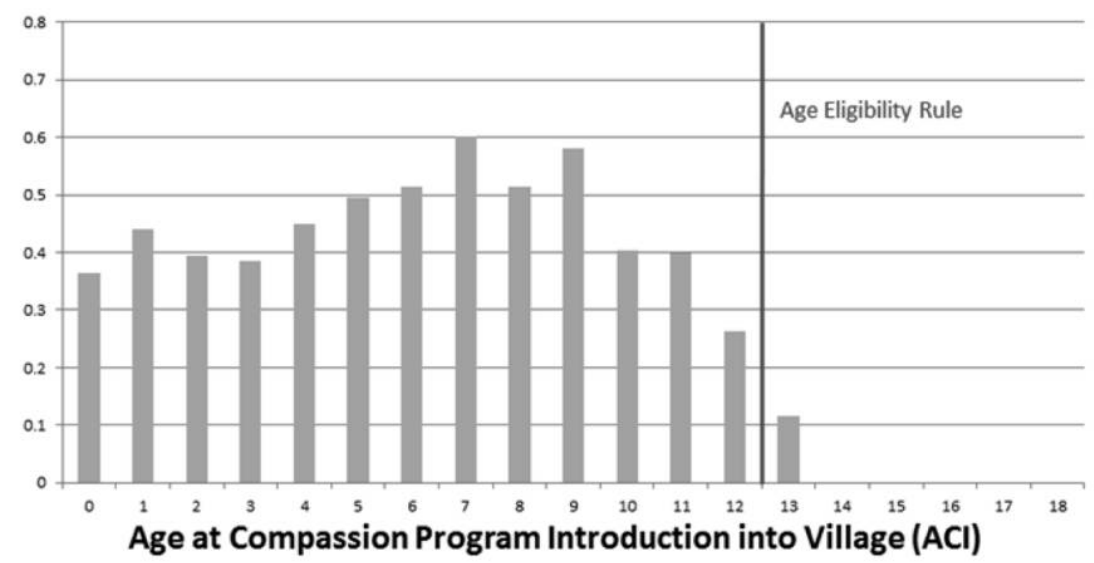

nercent Sponsored by ACl, Households with Sponsored Children

FIG. 1.-Discontinuity in sponsorship by age at time of program introduction. Mean: ACI $\leq 12,0.458$; ACI > 12, 0.022; difference: 0.436 . 


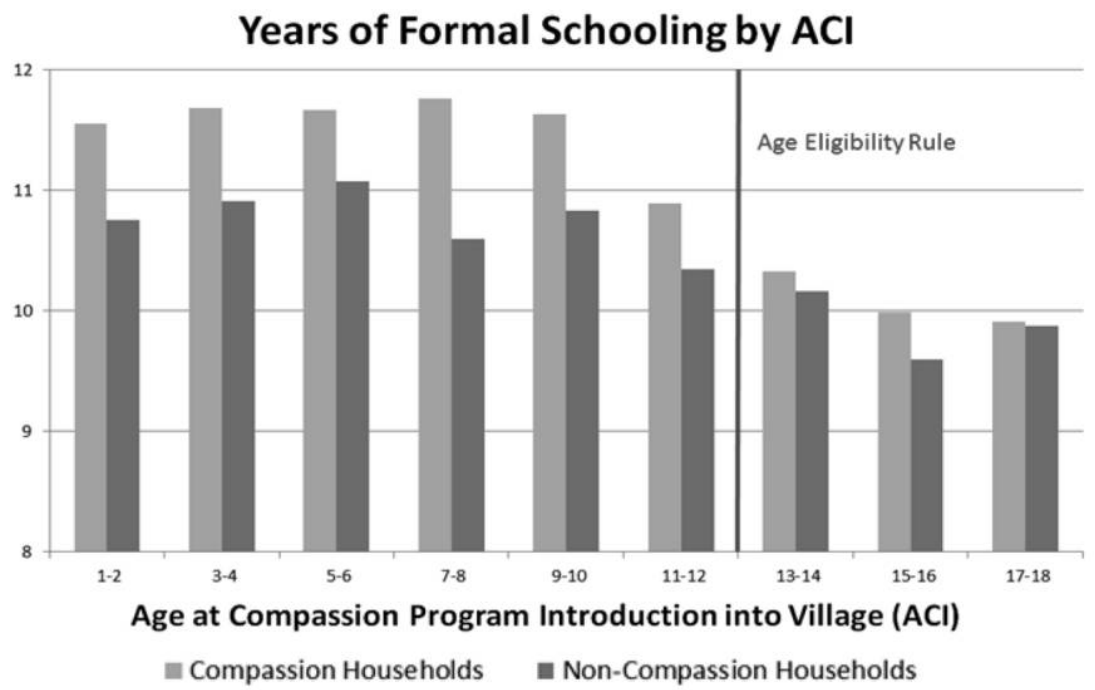

FIG. 2.- Total years of formal schooling by age when the Compassion program was introduced into a village (ACI). Means: Compassion households: $\mathrm{ACI} \leq 12,11.53$; ACI $>12$, 10.08; non-Compassion households: ACI $\leq 12$, 10.75; ACI > 12, 9.88; difference in differences: 0.58 .

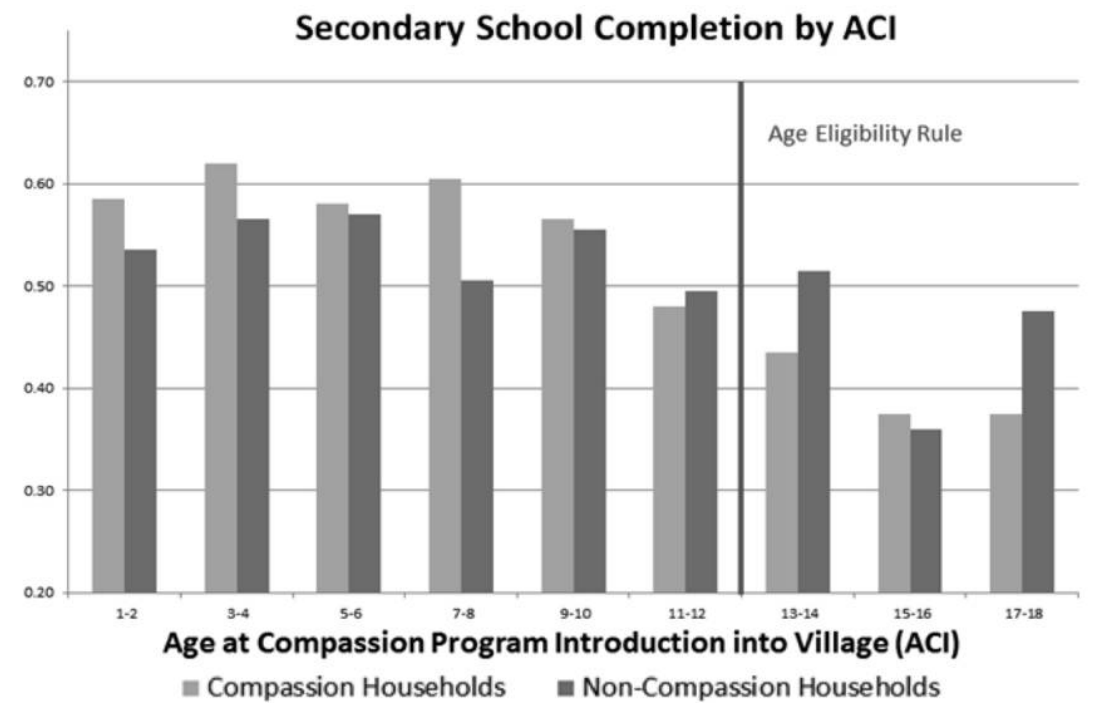

FIG. 3.-Secondary school completion by age when the Compassion program was introduced into a village (ACI). Means: Compassion households: ACI $\leq 12,0.57$; ACI $>12$, 0.39; non-Compassion households: $\mathrm{ACI} \leq 12,0.54$; ACI > 12, 0.45; difference in differences: 0.090 
households the difference between the average outcome for those with $\mathrm{ACI} \leq 12$ and the average for those with ACI $\geq 13$ is 1.47 years of schooling. For nontreated households the difference is 0.89 , so the difference in differences equals 0.58 year. Dividing this figure by the difference in the probability of sponsorship across these two ACI categories (0.436) suggests a 1.33-year impact of being sponsored, not accounting for controls. The analogous difference in differences in figure 3 for secondary school completion is 9.0 percentage points; dividing this by 0.436 suggests that sponsorship increases secondary completion by 20.6 percentage points, which could include spillovers onto other eligible children in Compassion households, but likewise does not adjust for control variables.

To estimate the impact of the program in a manner that more carefully controls for individual and household characteristics, we employ four regression specifications: ordinary least squares (OLS), a generalized method of moments instrumental variables estimator (IV-GMM), and both of these techniques adding household fixed effects (OLS-FE and IV-GMM-FE). These estimation methods must address three concerns to identify the impact of the Compassion program: (1) endogeneity in the selection of households into the program, (2) endogeneity in the selection of children within a particular household into the program, and (3) spillover effects from the program onto nontreated individuals in both Compassion and non-Compassion households in Compassion villages.

To address the first concern, our estimation strategy (a) allows for an additive, unobserved difference between selected and nonselected households in Compassion villages and an additive, unobserved difference between households in villages with and without the Compassion program; $(b)$ controls for individual and parental characteristics; and $(c)$ allows for unobserved household fixed effects (for two of the four regression specifications).

The second concern is the possibility of endogenous child selection within families. In practice, Compassion staff often select families for sponsorship, after which the families strongly influence which of their children are sponsored. Endogeneity in the choice of children within a family could bias estimates in either direction; selected children may have been chosen because they seemed of higher ability and so could realize larger gains from the program. Conversely, parents who have preferences for equal outcomes across all their children would select children whom they deem to be more in need of assistance than their siblings. It appeared to us in the field that the latter was more common, which is consistent with Compassion's guidelines for field personnel.

We address possible endogeneity in child selection by constructing instrumental variables on the basis of an individual's age and sibling order relative to the year of program rollout in his or her village (the former 
are ACI categories; the latter are oldest age-eligible child, second-oldest age-eligible child, etc.). These variables should not be related to adult life outcomes except through program participation, and they are highly correlated with the probability of sponsorship; thus they are valid instruments to address endogenous child selection. We observed that needier children tended to be selected for sponsorship from among age-eligible siblings, so we expect any bias in OLS estimates to be downward. Thus a priori we expect IV estimates to be larger than OLS estimates.

To address the third concern, spillover effects, each estimation method incorporates a difference-in-differences estimation strategy that allows for measurement of potential spillover effects onto nonsponsored individuals in both Compassion households and non-Compassion households in Compassion villages. Estimation of potential spillover effects rests on two identifying assumptions. The first is that spillovers do not flow from Compassion villages to non-Compassion villages. The second is that spillovers do not trickle from sponsored younger children up to older age-ineligible children in any households in Compassion villages.

While there is little reason to expect violations of the first assumption due to the distance between neighboring communities in our study, one objection to the second assumption is the possibility that sponsorship of younger age-eligible children affects their older age-ineligible siblings. Yet while there are good reasons to expect positive externalities to trickle down from sponsored children to younger unsponsored siblings, there is also good reason to expect that spillovers onto older age-ineligible siblings are much smaller, if not zero. Older siblings tend to be less influenced by their younger siblings' choices than vice versa. More important, education opportunities are usually accessible only within a relevant age range, beyond which older siblings have often passed, preventing them from emulating their younger siblings even if they wanted to do so.

To measure spillover effects onto nonsponsored age-eligible siblings in treated (Compassion) households, we compare differences in life outcomes between age-eligible children and their older age-ineligible siblings in Compassion households with the same differences between these two groups in nearby, nontreated villages. To estimate spillover effects from Compassion onto non-Compassion households in program villages, we compare differences in life outcomes between age-eligible siblings and their older age-ineligible siblings in nontreated households in Compassion villages with the same differences between these two groups in nearby non-Compassion villages. This is done by including dummy variables in the regression analysis that represent each of these groups.

More formally, we assign all individuals who were 16 or younger when the Compassion program began in their villages (or a neighboring village) to seven mutually exclusive categories: 
1. sponsored children, denoted by $T=1$, who were 12 or younger when the program started in their villages;

2. siblings of program participants who were 12 or younger when the program was introduced into their villages (denoted by $D_{1}^{\leq 12}=1$ ); they were eligible, but not selected, for the program;

3. siblings of program participants who were 13-16 when the program was introduced into their villages and thus were ineligible for the program $\left(D_{1}^{13-16}=1\right)$;

4. individuals in non-Compassion households in program villages who were 12 or younger when the program was introduced $\left(D_{2}^{\leq 12}=1\right)$;

5. individuals in non-Compassion households in program villages who were $13-16$ when the program was introduced $\left(D_{2}^{13-16}=1\right)$;

6. individuals in non-Compassion villages who were 12 or younger when the program was introduced in a neighboring village $\left(D_{3}^{\leq 12}\right.$ $=1$ ); and, finally,

7. individuals in non-Compassion villages who were $13-16$ when the program was introduced in a neighboring village $\left(D_{3}^{13-16}=1\right){ }^{6}$

These categories, and the associated notation, lead to the following regression equation:

$$
\begin{aligned}
y_{i}= & \alpha_{1} D_{1 i}^{\leq 12}+\alpha_{2} D_{1 i}^{13-16}+\tau\left(D_{1 i}^{\leq 12} \times T_{i}\right)+\beta_{1} D_{2 i}^{\leq 12}+\beta_{2} D_{2 i}^{13-16} \\
& +\gamma_{1} D_{3 i}^{\leq 12}+\gamma_{2} D_{3 i}^{13-16}+\delta C_{h}+\theta C_{v}+\boldsymbol{X}_{i} \phi+\epsilon_{i},
\end{aligned}
$$

where $y_{i}$ is the adult outcome of interest for person $i, C_{h}$ is a dummy variable indicating a household with a sponsored child, $C_{v}$ is a dummy variable indicating residence in a village with the Compassion program, and $\boldsymbol{X}_{i}$ is a vector of controls that include gender, age, age squared, birth order, number of siblings in a family, and mother's and father's education. $^{7}$

This framework allows us to estimate the causal impacts of the Compassion program under different assumptions about spillover effects. If we assume that (i) differences between villages with and without the

\footnotetext{
${ }^{6}$ Individuals 17 or older in program households are accounted for by the sum of the program household dummy variable and the program village dummy variable in eq. (1), and individuals 17 or older in program villages are accounted for by the program village dummy variable. Individuals 17 or older in nonprogram villages are the omitted category. Note also that $D_{1}^{\leq 12}=1$ for both sponsored children and their age-eligible siblings who were not chosen to be sponsored.

${ }^{7}$ A more flexible specification would allow $\tau$ to vary for each ACI category (ACI $=12$, $\mathrm{ACI}=11$, etc.), and similarly for $\alpha_{1}, \alpha_{2}, \beta_{1}, \beta_{2}, \gamma_{1}$, and $\gamma_{2}$. We tested the restrictions in eq. (1) that $\tau$ is the same for all sponsored children (i.e., does not vary by ACI) and the analogous restrictions for $\alpha_{1}, \alpha_{2}, \beta_{1}, \beta_{2}, \gamma_{1}$, and $\gamma_{2}$ and the same restrictions in eq. (3) below, and we cannot reject the hypothesis that these restrictions hold. Unrestricted estimates, as well as the tests of these restrictions, are available from the authors on request.
} 
Compassion program can be fully represented by $\theta C_{v}$ and the observed covariates $\boldsymbol{X}$; (ii) differences between participating and nonparticipating households in villages where Compassion has a program can be represented by $\delta C_{h}$ and the observed covariates $\boldsymbol{X}$; (iii) there are no intrafamily, intravillage, and intervillage spillover effects; and (iv) intrafamily child selection is random, then OLS estimates of equation (1) would consistently estimate $\tau$, the impact of the sponsorship program on $y_{i}$. Moreover, we can test whether these assumptions are reasonable. For example, continuing to assume no spillovers onto individuals with ACI $\geq 1$, assumptions $\mathrm{i}$ and ii imply that $\alpha_{2}=\beta_{2}=\gamma_{2}\left(C_{h}, C_{v}\right.$, and the observed covariates $\boldsymbol{X}$ fully account for differences between individuals with ACI of 13-16 in Compassion households, non-Compassion households in Compassion villages, and households in non-Compassion villages, so there is no need for these three parameters to differ), and adding assumption iii implies that $\alpha_{1}=\beta_{1}=\gamma_{1}$ (without intrahousehold or intravillage spillovers, there is also no reason for these three parameters to differ).

Alternatively, if assumptions i and ii hold but assumption iii does not, intrahousehold spillovers onto nontreated eligible siblings can be estimated as explained above by the difference in differences, $\left(\alpha_{1}-\alpha_{2}\right)-$ $\left(\gamma_{1}-\gamma_{2}\right)$, and intravillage spillovers among children 12 and younger can be estimated by $\left(\beta_{1}-\beta_{2}\right)-\left(\gamma_{1}-\gamma_{2}\right)$. If spillovers exist, then the full treatment effect is no longer estimated by $\tau$ alone. If there are intrahousehold spillovers, the full program effect on the treated can be estimated by $\tau+\left(\alpha_{1}-\alpha_{2}\right)-\left(\gamma_{1}-\gamma_{2}\right)$. That is, $\tau$ estimates the impact of the program on a treated child relative to his or her siblings of similar age; but since those siblings experienced spillover effects, one needs to add this spillover effect to $\tau$ to obtain the full program impact on the treated child.

Our IV estimations use a vector of instruments comprising interactions between dummy variables for a child's age at program introduction (ACI) and dummy variables for sibling order relative to program rollout (SORR). ${ }^{8}$ These dummy variables have strong predictive power for the child(ren) chosen by parents for the program because of parents' tendency to choose the oldest age-eligible siblings for sponsorship. ${ }^{9}$ Moreover, they plausibly satisfy the exclusion restriction for equation (1) since there is no reason why, after controlling for characteristic variables $(\boldsymbol{X})$, a child's age at the time of program rollout interacted with SORR

\footnotetext{
${ }^{8}$ SORR consists of three dummy variables: oldest sibling among age-eligible siblings at time of program rollout, second oldest of such siblings at time of program rollout, and third or higher oldest of such siblings at time of program rollout.

${ }^{9}$ Among children in Compassion households, the probability of the two oldest ageeligible children being sponsored was 51.5 percent (average over all six countries), compared to only 20.4 percent for all other age-eligible children.
} 
should affect adult life outcomes except via its effect on the probability of sponsorship.

In addition to aggregating age categories (12 or less and 13-16), we also aggregated our instrumental variables. ${ }^{10}$ This is done to avoid potential problems due to including large numbers of instruments that individually may be weak and to provide more reliable asymptotic results given that the sample is divided into only 32 clusters (villages). We maintained the distinction between children who were the oldest eligible sibling, the second-oldest eligible sibling, and all other eligible siblings, but we grouped individuals by ACI into three categories: 5 or younger, $6-8$, and 9-12, yielding nine instruments of the form $\boldsymbol{Z}_{1 i}^{\mathrm{ACI}}=\left(\boldsymbol{D}_{1 i}^{\mathrm{ACI}} \otimes \mathbf{S O R R}\right)$. Other variations in the age aggregation of the instruments yield very similar results.

Thus for IV estimates the first-stage estimation is

$$
\begin{aligned}
T_{i}= & \tilde{\alpha}_{1} D_{1 i}^{\leq 12}+\tilde{\alpha}_{2} D_{1 i}^{13-16}+\tilde{\beta}_{1} D_{2 i}^{\leq 12}+\tilde{\beta}_{2} D_{2 i}^{13-16}+\tilde{\gamma}_{1} D_{3 i}^{\leq 12}+\tilde{\gamma}_{2} D_{3 i}^{13-16} \\
& +\tilde{\delta} C_{h}+\tilde{\theta} C_{v}+\boldsymbol{X}_{i} \tilde{\varphi}+Z_{1 i}^{\mathrm{ACI}} \tilde{\pi}+e_{i}
\end{aligned}
$$

and the second stage is

$$
\begin{aligned}
y_{i}= & \alpha_{1} D_{1 i}^{\leq 12}+\alpha_{2} D_{1 i}^{13-16}+\tau\left(D_{1 i}^{\leq 12} \hat{T}_{i}\right)+\beta_{1} D_{2 i}^{\leq 12}+\beta_{2} D_{2 i}^{13-16}+\gamma_{1} D_{3 i}^{\leq 12} \\
& +\gamma_{2} D_{3 i}^{13-16}+\delta C_{h}+\theta C_{v} \boldsymbol{\epsilon}+\boldsymbol{X}_{i} \boldsymbol{\varphi}+\epsilon_{i},
\end{aligned}
$$

where $\hat{T}_{i j}$ is the predicted probability of being sponsored. Equations (2) and $\left(2^{\prime}\right)$ are estimated using GMM, which is more efficient than standard IV estimates and allows one to carry out J-tests of overidentifying restrictions to check the validity of the instruments.

We also present OLS and (GMM) IV household fixed-effect estimates, which control more directly for interhousehold unobservables that could affect child selection. The main disadvantage is that the large number of fixed effects may reduce the precision of the estimates. The OLS-FE estimate for child $i$ in household $j$ is

$$
\begin{aligned}
y_{i j}= & \alpha_{1} D_{1 i j}^{\leq 12}+\alpha_{2} D_{1 i j}^{13-16}+\tau\left(D_{1 i j}^{\leq 12} \times T_{i}\right)+\beta_{1} D_{2 i j}^{\leq 12}+\beta_{2} D_{2 i j}^{13-16} \\
& +\gamma_{1} D_{3 i j}^{\leq 12}+\gamma_{2} D_{3 i j}^{13-16}+\boldsymbol{X}_{i j} \varphi+\theta_{j}+\epsilon_{i j},
\end{aligned}
$$

where $\theta_{j}$ is a household fixed effect and other variables are as defined previously. For IV-GMM-FE, the first-stage equations are given by

\footnotetext{
${ }^{10}$ Results are similar when we retain all 54 instrumental variables.
} 


$$
\begin{aligned}
T_{i j}= & \tilde{\alpha}_{1} D_{1 i j}^{\leq 12}+\tilde{\alpha}_{2} D_{1 i j}^{13-16}+\tilde{\beta}_{1} D_{2 i j}^{\leq 12}+\tilde{\beta}_{2} D_{2 i j}^{13-16}+\tilde{\gamma}_{1} D_{3 i j}^{\leq 12} \\
& +\tilde{\gamma}_{2} D_{3 i j}^{13-16}+\boldsymbol{X}_{i j} \tilde{\boldsymbol{\varphi}}+\boldsymbol{Z}_{i j}^{\mathrm{ACI}} \tilde{\pi}+\tilde{\theta}_{j}+\tilde{\epsilon}_{i l},
\end{aligned}
$$

where $\tilde{\theta}_{j}$ is also a household fixed effect, and $\boldsymbol{Z}_{i j}^{\mathrm{ACI}}$ is the same vector of instruments used in equation (3). The second-stage equation of the household fixed-effects estimation is

$$
\begin{aligned}
y_{i j}= & \alpha_{1} D_{1 i j}^{\leq 12}+\alpha_{2} D_{1 i j}^{13-16}+\tau\left(D_{1 i j}^{\leq 12} \hat{T}_{i}\right)+\beta_{1} D_{2 i j}^{\leq 12}+\beta_{2} D_{2 i j}^{13-16} \\
& +\gamma_{1} D_{3 i j}^{\leq 12}+\gamma_{2} D_{3 i j}^{13-16}+\theta_{j}+\boldsymbol{X}_{i j} \varphi+\epsilon_{i j} .
\end{aligned}
$$

\section{Empirical Results}

This section presents estimates of the impact of child sponsorship on completed years of schooling and on the probabilities of completing primary, secondary, and tertiary education. It also summarizes estimates of impacts on employment and leadership and presents robustness checks.

\section{A. Estimates of Impact on Education}

Table 4 provides, by country, descriptive statistics of the outcome variables and the main control variables. Table 5 shows how the outcome variables differ between all sponsored children (col. 1), all nonsponsored children in the sample (cols. 2 and 3), and nonsponsored siblings of sponsored children (cols. 4 and 5). Simple $t$-tests in table 5 that do not account for the influence of control variables show statistically significant differences in all these adult life outcomes, including formal years of schooling, where sponsored children realize 1.38 more years of schooling than their unsponsored siblings and 1.79 more years of schooling than their unsponsored peers.

Tables $6-9$ provide estimates of equations $(1),\left(2^{\prime}\right),(3)$, and $\left(4^{\prime}\right)$, that is, estimates based on OLS, IV-GMM, OLS with household-level fixed effects, and IV-GMM with household-level fixed effects. The education outcomes differ for each table; years of completed schooling are in table 6 , and primary, secondary, and university completion are in tables 7, 8, and 9, respectively. OLS estimates of the impact of Compassion sponsorship on completed years of formal schooling in column 1 of table 6 show a highly significant estimated direct impact $(\tau)$ of a little over 1 year (1.03 years). The coefficients on the other categories of individuals in the next six rows of the table measure differences in educational outcomes between those individuals and individuals in the same type of household who were 17 or older when the Compassion program was introduced in their village (or a nearby village). For example, the second (third) row sug- 
TABLE 5

Summary Means and $t$-Tests of Education Variables

\begin{tabular}{|c|c|c|c|c|c|}
\hline & $\begin{array}{c}\text { Mean, Sponsored } \\
\text { Individuals } \\
(1)\end{array}$ & $\begin{array}{c}\text { Mean, All } \\
\text { Nonsponsored } \\
\text { Individuals } \\
\text { (2) }\end{array}$ & $\begin{array}{c}\text { Difference } \\
t \text {-Test } \\
(3)\end{array}$ & $\begin{array}{c}\text { Mean, } \\
\text { Nonsponsored } \\
\text { Siblings in } \\
\text { Sponsored } \\
\text { Households } \\
(4)\end{array}$ & $\begin{array}{c}\text { Difference } \\
t \text {-Test } \\
(5)\end{array}$ \\
\hline $\begin{array}{c}\text { Total years of } \\
\text { education }\end{array}$ & $\begin{array}{l}12.03 \\
(2.79)\end{array}$ & $\begin{array}{l}10.24 \\
(3.74)\end{array}$ & $\begin{array}{l}1.79 * * * \\
(.093)\end{array}$ & $\begin{array}{l}10.65 \\
(3.41)\end{array}$ & $\begin{array}{l}1.38 * * * \\
(.092)\end{array}$ \\
\hline $\begin{array}{c}\text { Completed } \\
\text { primary }\end{array}$ & $\begin{array}{l}.984 \\
(.127)\end{array}$ & $\begin{array}{l}.887 \\
(.316)\end{array}$ & $\begin{array}{l}.096 * * * \\
(.0075)\end{array}$ & $\begin{array}{l}.927 \\
(.260)\end{array}$ & $\begin{array}{l}.057 * * * \\
(.0064)\end{array}$ \\
\hline $\begin{array}{l}\text { Completed } \\
\text { secondary }\end{array}$ & $\begin{array}{l}.646 \\
(.478)\end{array}$ & $\begin{array}{l}.449 \\
(.497)\end{array}$ & $\begin{array}{l}.196^{* * * *} \\
(.013)\end{array}$ & $\begin{array}{l}.460 \\
(.498)\end{array}$ & $\begin{array}{l}.185^{* * *} \\
(.014)\end{array}$ \\
\hline $\begin{array}{l}\text { Completed } \\
\text { university }\end{array}$ & $\begin{array}{l}.078 \\
(.268)\end{array}$ & $\begin{array}{l}.043 \\
(.203)\end{array}$ & $\begin{array}{l}.035 * * * \\
(.0056)\end{array}$ & $\begin{array}{l}.049 \\
(.216)\end{array}$ & $\begin{array}{l}.029 * * * \\
(.007)\end{array}$ \\
\hline
\end{tabular}

Note.- In cols.1, 2, and 4, numbers in parentheses are standard deviations. In cols. 3 and 5, numbers in parentheses are standard errors. Full sample size is 10,011. Number of formerly sponsored individuals is 1,834 . Number of individuals in nontreated households is 4,560 . Number of nonsponsored individuals in treated households is 3,617 .

* Significant at 10 percent.

** Significant at 5 percent.

*** Significant at 1 percent.

gests that children who were 12 and younger (13-16) in Compassion households when the program was introduced but did not participate in the program eventually attained about $0.42(0.17)$ more year of schooling than their siblings who were 17 or older when the program began, but neither difference is statistically significant. Similarly, rows 4 and 5 compare younger household members to those aged 17 and older in non-Compassion households in Compassion villages, and rows 6 and 7 do the same among those in non-Compassion villages. The assumption that the general specification used in equations (1)-(4) is reasonablemore specifically, that $C_{h}, C_{v}$, and the observed covariates in $\boldsymbol{X}$ adequately account for differences between individuals with ACI of 13-16 across Compassion households, non-Compassion households in Compassion villages, and households in non-Compassion villages, which implies that $\alpha_{2}=\beta_{2}=\gamma_{2}$-is tested in the eighth row of table 6 and is not rejected.

The results in table 6 also allow one to test for spillover effects, as explained in Section IV. The first check for possible spillovers is to test the assumption of "parallel trends" among nonsponsored students with $\mathrm{ACI} \leq 12$ in the three types of households, which implies $\alpha_{1}=\beta_{1}=\gamma_{1}$; this is not rejected (ninth row). The tenth row of table 6 directly checks for intrahousehold spillovers by comparing the difference in years of schooling between nonparticipating individuals with ACI 12 or below 
TABLE 6

OLS and IV Estimates of Equations (1), $\left(2^{\prime}\right)$, (3), and $\left(4^{\prime}\right)$ : Years of Schooling

\begin{tabular}{|c|c|c|c|c|}
\hline Variable & $\begin{array}{l}\text { OLS } \\
(1)\end{array}$ & $\begin{array}{l}\text { IV-GMM } \\
(2)\end{array}$ & $\begin{array}{l}\text { OLS-FE } \\
(3)\end{array}$ & $\begin{array}{c}\text { IV-GMM-FE } \\
(4)\end{array}$ \\
\hline Program participant $(\tau)$ & $\begin{array}{l}1.034 * * * \\
(.152)\end{array}$ & $\begin{array}{l}1.383 * * * \\
(.441)\end{array}$ & $\begin{array}{l}1.118^{* * * *} \\
(.121)\end{array}$ & $\begin{array}{l}1.455^{* * * *} \\
(.407)\end{array}$ \\
\hline \multicolumn{5}{|l|}{ Compassion household: } \\
\hline $\mathrm{ACI} \leq 12\left(\alpha_{1}\right)$ & $\begin{array}{l}.421 \\
(.555)\end{array}$ & $\begin{array}{c}-.069 \\
(.330)\end{array}$ & $\begin{array}{l}.720 \\
(.432)\end{array}$ & $\begin{array}{l}.765 \\
(.475)\end{array}$ \\
\hline ACI $13-16\left(\alpha_{2}\right)$ & $\begin{array}{l}.169 \\
(.417)\end{array}$ & $\begin{array}{l}-.236 \\
(.251)\end{array}$ & $\begin{array}{l}.039 \\
(.265)\end{array}$ & $\begin{array}{l}.082 \\
(.207)\end{array}$ \\
\hline \multicolumn{5}{|l|}{ Program village: } \\
\hline $\mathrm{ACI} \leq 12\left(\beta_{1}\right)$ & $\begin{array}{l}.588 \\
(.611)\end{array}$ & $\begin{array}{l}.476 \\
(.437)\end{array}$ & $\begin{array}{l}.897 * * \\
(.436)\end{array}$ & $\begin{array}{l}.916 \\
(.579)\end{array}$ \\
\hline ACI $13-16\left(\beta_{2}\right)$ & $\begin{array}{c}-.013 \\
(.533)\end{array}$ & $\begin{array}{l}-.205 \\
(.430)\end{array}$ & $\begin{array}{l}.414 \\
(.459)\end{array}$ & $\begin{array}{l}.405 \\
(.468)\end{array}$ \\
\hline \multicolumn{5}{|l|}{ Nonprogram village: } \\
\hline $\mathrm{ACI} \leq 12\left(\gamma_{1}\right)$ & $\begin{array}{l}.690 \\
(.734)\end{array}$ & $\begin{array}{l}.248 \\
(.697)\end{array}$ & $\begin{array}{c}-.085 \\
(.504)\end{array}$ & $\begin{array}{l}.047 \\
(.435)\end{array}$ \\
\hline ACI $13-16\left(\gamma_{2}\right)$ & $\begin{array}{l}.161 \\
(.523)\end{array}$ & $\begin{array}{l}.041 \\
(.486)\end{array}$ & $\begin{array}{c}-.525^{* *} \\
(.197)\end{array}$ & $\begin{array}{c}-.499 * * * \\
(.185)\end{array}$ \\
\hline \multicolumn{5}{|l|}{$F$-tests $/ \chi^{2}$ tests of parallel trends: } \\
\hline$\alpha_{2}=\beta_{2}=\gamma_{2}$ & $\begin{array}{l}.08 \\
{[.926]}\end{array}$ & $\begin{array}{l}.26 \\
{[.877]}\end{array}$ & $\begin{array}{l}2.26 \\
{[.121]}\end{array}$ & $\begin{array}{c}6.08 * * \\
{[.048]}\end{array}$ \\
\hline$\alpha_{1}=\beta_{1}=\gamma_{1}$ & $\begin{array}{l}.07 \\
{[.935]}\end{array}$ & $\begin{array}{l}1.54 \\
{[.464]}\end{array}$ & $\begin{array}{l}1.03 \\
{[.368]}\end{array}$ & $\begin{array}{l}1.38 \\
{[.501]}\end{array}$ \\
\hline $\begin{array}{l}\text { Intrahousehold spillovers: } \\
\qquad\left(\alpha_{1}-\alpha_{2}\right)-\left(\gamma_{1}-\gamma_{2}\right)\end{array}$ & $\begin{array}{c}-.277 \\
(.686)\end{array}$ & $\begin{array}{c}-.039 \\
(.686)\end{array}$ & $\begin{array}{l}.240 \\
(.516)\end{array}$ & $\begin{array}{l}.137 \\
(.555)\end{array}$ \\
\hline $\begin{array}{l}\text { Intravillage spillovers: } \\
\qquad\left(\beta_{1}-\beta_{2}\right)-\left(\gamma_{1}-\gamma_{2}\right)\end{array}$ & $\begin{array}{l}.072 \\
(.631)\end{array}$ & $\begin{array}{l}.474 \\
(.584)\end{array}$ & $\begin{array}{l}.043 \\
(.540)\end{array}$ & $\begin{array}{c}-.036 \\
(.529)\end{array}$ \\
\hline \multicolumn{5}{|l|}{$\begin{array}{l}\text { Program impact including } \\
\text { intrahousehold spillovers: }\end{array}$} \\
\hline$\tau+\left(\alpha_{1}-\alpha_{2}\right)-\left(\gamma_{1}-\gamma_{2}\right)$ & $\begin{array}{l}.757 \\
(.678)\end{array}$ & $\begin{array}{l}1.344^{*} \\
(.713)\end{array}$ & $\begin{array}{l}1.359 * * \\
(.506)\end{array}$ & $\begin{array}{l}1.592 * * * \\
(.446)\end{array}$ \\
\hline Hausman test $[p$-value $]$ & $\ldots$ & {$[.969]$} & $\ldots$ & {$[.922]$} \\
\hline Overidentification $(J$-test $)[p$-value $]$ & $\ldots$ & $\begin{array}{l}9.30 \\
{[.232]}\end{array}$ & $\ldots$ & $\begin{array}{l}6.05 \\
{[.534]}\end{array}$ \\
\hline Weak IV test (F-statistic) & & 60.03 & . . & 48.93 \\
\hline Observations & 9,954 & 9,954 & 9,954 & 9,954 \\
\hline$R^{2}$ & .253 & .250 & .064 & .047 \\
\hline
\end{tabular}

Note.-Clustered standard errors at the village level are in parentheses. Each regression includes controls for age at program introduction (ACI) at age 12 and below and at ages 13-16, age, age squared, birth order, gender, status as oldest child, mother's education, father's education, mother's education missing, and father's education missing.

* Significant at 10 percent.

** Significant at 5 percent.

*** Significant at 1 percent.

and those with ACI 13-16 in Compassion households with the same difference for individuals in nearby non-Compassion villages. The insignificance of this double difference, $\left(\alpha_{1}-\alpha_{2}\right)-\left(\gamma_{1}-\gamma_{2}\right)$, yields no evidence for intrahousehold spillovers from sponsored children to age-eligible nonsponsored siblings in Compassion households. The eleventh row tests 
for spillovers within villages by comparing the difference between individuals with ACI 12 or below and those with ACI 13-16 in non-Compassion households in Compassion villages with the same difference in nonCompassion villages, $\left(\beta_{1}-\beta_{2}\right)-\left(\gamma_{1}-\gamma_{2}\right)$. Thus there is no evidence of intravillage spillovers from Compassion households onto age-eligible children in non-Compassion households in Compassion villages.

The impact on program participants that includes possible spillover effects, $\tau+\left(\alpha_{1}-\alpha_{2}\right)-\left(\gamma_{1}-\gamma_{2}\right)$, is in the twelfth row of table 6 . This "full" program impact is somewhat smaller than the direct program impact (0.76 vs. 1.03) and is statistically insignificant. Yet the lack of statistical significance is due to adding the four statistically insignificant parameters that attempt to capture spillovers to the estimate of the direct impact. Because the spillover estimates are insignificant, our preferred estimate of the Compassion program's impact on years of schooling is the direct impact $(\tau)$, which is 1.03 .

Column 2 of table 6 presents IV estimates of the impact of the Compassion program on years of schooling, which are somewhat higher (direct impact of 1.38 years). Note that the exclusion restrictions are not rejected by the overidentification test $(p$-value $=.232)$, and the $F$-test of the explanatory power of the excluded instruments is quite large (60.03). However, the Hausman test does not reject the hypothesis that the OLS and IV estimates are equal ( $p$-value $=.969)$. As with the OLS estimates, there is no evidence of intrahousehold or intravillage spillovers, and the "full" program effect on participants (1.34 years) is very similar to the direct effect (1.38), though it is significant only at the 10 percent level because of the imprecision of the estimated spillover effects.

Columns 3 and 4 carry out the same estimates in columns 1 and 2 but add household fixed effects. Estimates of direct impacts $(\tau)$ are slightly higher, at 1.12 and 1.46 years. Although the program effect including spillovers, $\tau+\left(\alpha_{1}-\alpha_{2}\right)-\left(\gamma_{1}-\gamma_{2}\right)$, is estimated to be somewhat higher (1.36 and 1.59 years, respectively), there is no significant evidence of spillovers, so the estimates of the direct impacts in table 6 are our preferred measures of impact. ${ }^{11}$

Estimation results for primary school completion are shown in table 7 . The estimates of the direct impact $(\tau)$ are generally significant but small, probably because of the relatively high rate of baseline primary school completion in these villages (88.7 percent). These estimates are similar across columns, ranging from 4.0 (OLS estimates) to 7.7 percentage points (IV estimates without fixed effects). All except the fixed-effect IV estimate in column 4 are significant at the 1 percent level. There is no

\footnotetext{
${ }^{11}$ There is marginally significant evidence that the parallel trends assumption is violated in the IV-GMM-FE specification $(p$-value $=.048)$, but since the seven other tests of parallel trends in table 6 do not reject that assumption and the Hausman test does not indicate a need for IV estimation, we do not view this as a major cause for concern.
} 
TABLE 7

OLS ANd IV Estimates of Equations (1), $\left(2^{\prime}\right)$, (3), AND $\left(4^{\prime}\right)$ : Primary School Completion

\begin{tabular}{|c|c|c|c|c|}
\hline Variable & $\begin{array}{l}\text { OLS } \\
(1)\end{array}$ & $\begin{array}{l}\text { IV-GMM } \\
\quad(2)\end{array}$ & $\begin{array}{l}\text { OLS-FE } \\
(3)\end{array}$ & $\begin{array}{l}\text { IV-GMM-FE } \\
(4)\end{array}$ \\
\hline Program participant $(\tau)$ & $\begin{array}{l}.0404 * * * \\
(.0086)\end{array}$ & $\begin{array}{l}.0771 * * * \\
(.0282)\end{array}$ & $\begin{array}{l}.0493^{* * * *} \\
(.0097)\end{array}$ & $\begin{array}{l}.0503 \\
(.0453)\end{array}$ \\
\hline \multicolumn{5}{|l|}{ Compassion household: } \\
\hline $\mathrm{ACI} \leq 12\left(\alpha_{1}\right)$ & $\begin{array}{l}.0171 \\
(.0540)\end{array}$ & $\begin{array}{r}-.0133 \\
(.0288)\end{array}$ & $\begin{array}{l}.0199 \\
(.0382)\end{array}$ & $\begin{array}{l}.0358 \\
(.0284)\end{array}$ \\
\hline ACI $13-16\left(\alpha_{2}\right)$ & $\begin{array}{l}.0042 \\
(.0437)\end{array}$ & $\begin{array}{c}-.0243 \\
(.0303)\end{array}$ & $\begin{array}{c}-.0062 \\
(.0261)\end{array}$ & $\begin{array}{l}.0069 \\
(.0175)\end{array}$ \\
\hline \multicolumn{5}{|l|}{ Program village: } \\
\hline $\mathrm{ACI} \leq 12\left(\beta_{1}\right)$ & $\begin{array}{l}.0367 \\
(.0574)\end{array}$ & $\begin{array}{l}.0062 \\
(.0493)\end{array}$ & $\begin{array}{l}.0657 * * \\
(.0311)\end{array}$ & $\begin{array}{l}.0468 \\
(.0374)\end{array}$ \\
\hline ACI 13-16 $\left(\beta_{2}\right)$ & $\begin{array}{c}-.0217 \\
(.0480)\end{array}$ & $\begin{array}{r}-.0507 \\
(.0402)\end{array}$ & $\begin{array}{l}.0205 \\
(.0312)\end{array}$ & $\begin{array}{l}.0119 \\
(.0337)\end{array}$ \\
\hline \multicolumn{5}{|l|}{ Nonprogram village: } \\
\hline $\mathrm{ACI} \leq 12\left(\gamma_{1}\right)$ & $\begin{array}{l}.0658 \\
(.0773)\end{array}$ & $\begin{array}{l}-.0079 \\
(.0714)\end{array}$ & $\begin{array}{l}.0133 \\
(.0493)\end{array}$ & $\begin{array}{c}-.0058 \\
(.0448)\end{array}$ \\
\hline ACI $13-16\left(\gamma_{2}\right)$ & $\begin{array}{l}.0019 \\
(.0550)\end{array}$ & $\begin{array}{l}.0157 \\
(.0479)\end{array}$ & $\begin{array}{c}-.0288 \\
(.0211)\end{array}$ & $\begin{array}{c}-.0355^{*} \\
(.0194)\end{array}$ \\
\hline \multicolumn{5}{|l|}{$\begin{array}{l}F \text {-tests } / \chi^{2} \text { tests of parallel } \\
\text { trends: }\end{array}$} \\
\hline$\alpha_{2}=\beta_{2}=\gamma_{2}$ & $\begin{array}{l}.16 \\
{[.856]}\end{array}$ & $\begin{array}{l}1.20 \\
{[.548]}\end{array}$ & $\begin{array}{l}.98 \\
{[.388]}\end{array}$ & $\begin{array}{l}3.20 \\
{[.202]}\end{array}$ \\
\hline$\alpha_{1}=\beta_{1}=\gamma_{1}$ & $\begin{array}{l}.17 \\
{[.846]}\end{array}$ & $\begin{array}{l}.22 \\
{[.894]}\end{array}$ & $\begin{array}{l}.74 \\
{[.487]}\end{array}$ & $\begin{array}{l}.72 \\
{[.698]}\end{array}$ \\
\hline $\begin{array}{l}\text { Intrahousehold spillovers: } \\
\qquad\left(\alpha_{1}-\alpha_{2}\right)-\left(\gamma_{1}-\gamma_{2}\right)\end{array}$ & $\begin{array}{r}-.0511 \\
(.0719)\end{array}$ & $\begin{array}{c}.0347 \\
(.0708)\end{array}$ & $\begin{array}{r}-.0160 \\
(.0534)\end{array}$ & $\begin{array}{c}-.0007 \\
(.0532)\end{array}$ \\
\hline $\begin{array}{l}\text { Intravillage spillovers: } \\
\qquad\left(\beta_{1}-\beta_{2}\right)-\left(\gamma_{1}-\gamma_{2}\right)\end{array}$ & $\begin{aligned}-.0056 \\
(.0693)\end{aligned}$ & $\begin{array}{l}.0805 \\
(.0666)\end{array}$ & $\begin{array}{l}.0030 \\
(.0568)\end{array}$ & $\begin{array}{l}.0053 \\
(.0451)\end{array}$ \\
\hline \multicolumn{5}{|l|}{$\begin{array}{l}\text { Program impact including } \\
\text { intrahousehold spillovers: }\end{array}$} \\
\hline \multicolumn{5}{|l|}{ Overidentification ( $J$-test) } \\
\hline [p-value $]$ & $\ldots$ & $\begin{array}{l}9.47 \\
{[.220]}\end{array}$ & $\cdots$ & $\begin{array}{l}8.23 \\
{[.313]}\end{array}$ \\
\hline Weak IV test ( $F$-statistic) & & 60.03 & 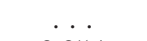 & 48.93 \\
\hline Observations & 9,954 & 9,954 & 9,954 & 9,954 \\
\hline$R^{2}$ & .123 & .104 & .031 & .030 \\
\hline
\end{tabular}

Note.-Clustered standard errors at the village level are in parentheses. Each regression includes controls for age at program introduction (ACI) at age 12 and below and at ages 13-16, age, age squared, birth order, gender, status as oldest child, mother's education, father's education, mother's education missing, and father's education missing.

* Significant at 10 percent.

** Significant at 5 percent.

*** Significant at 1 percent. 
evidence of spillovers either within households or within Compassion villages.

Table 8 presents estimates of the probability of completing secondary school. Because the Compassion program typically sponsors children to the end of secondary school, this is a natural level of school completion

TABLE 8

OLS ANd IV Estimates of Equations (1), $\left(2^{\prime}\right)$, (3), And $\left(4^{\prime}\right)$ : Secondary School Completion

\begin{tabular}{|c|c|c|c|c|}
\hline Variable & $\begin{array}{l}\text { OLS } \\
(1)\end{array}$ & $\begin{array}{l}\text { IV-GMM } \\
(2)\end{array}$ & $\begin{array}{l}\text { OLS-FE } \\
(3)\end{array}$ & $\begin{array}{c}\text { IV-GMM-FE } \\
(4) \\
\end{array}$ \\
\hline Program participant $(\tau)$ & $\begin{array}{l}.1324 * * * \\
(.0275)\end{array}$ & $\begin{array}{l}.1648^{*} \\
(.0937)\end{array}$ & $\begin{array}{l}.1160 * * * \\
(.0172)\end{array}$ & $\begin{array}{l}.0624 \\
(.0846)\end{array}$ \\
\hline \multicolumn{5}{|l|}{ Compassion household: } \\
\hline ACI $\leq 12\left(\alpha_{1}\right)$ & $\begin{array}{r}-.0266 \\
(.0523)\end{array}$ & $\begin{array}{r}-.0574 \\
(.0582)\end{array}$ & $\begin{array}{l}.0934 * \\
(.0553)\end{array}$ & $\begin{array}{l}.1669 * * * \\
(.0638)\end{array}$ \\
\hline ACI $13-16\left(\alpha_{2}\right)$ & $\begin{array}{r}-.0236 \\
(.0385)\end{array}$ & $\begin{array}{r}-.0495^{*} \\
(.0267)\end{array}$ & $\begin{array}{r}-.0060 \\
(.0339)\end{array}$ & $\begin{array}{l}.0219 \\
(.0238)\end{array}$ \\
\hline \multicolumn{5}{|l|}{ Program village: } \\
\hline $\mathrm{ACI} \leq 12\left(\beta_{1}\right)$ & $\begin{array}{r}-.0113 \\
(.0589)\end{array}$ & $\begin{array}{r}-.0092 \\
(.0387)\end{array}$ & $\begin{array}{l}.1126 \\
(.0751)\end{array}$ & $\begin{array}{l}.1655 \\
(.1094)\end{array}$ \\
\hline ACI $13-16\left(\beta_{2}\right)$ & $\begin{aligned}-.0324 \\
(.0615)\end{aligned}$ & $\begin{aligned}-.0551 \\
(.0447)\end{aligned}$ & $\begin{array}{l}.0554 \\
(.0764)\end{array}$ & $\begin{array}{l}.0810 \\
(.0873)\end{array}$ \\
\hline \multicolumn{5}{|l|}{ Nonprogram village: } \\
\hline $\mathrm{ACI} \leq 12\left(\gamma_{1}\right)$ & $\begin{array}{r}-.0219 \\
(.0602)\end{array}$ & $\begin{array}{r}-.0134 \\
(.0579)\end{array}$ & $\begin{array}{r}-.0323 \\
(.0495)\end{array}$ & $\begin{aligned}-.0076 \\
(.0445)\end{aligned}$ \\
\hline ACI $13-16\left(\gamma_{2}\right)$ & $\begin{array}{r}-.0143 \\
(.0449)\end{array}$ & $\begin{array}{r}-.0082 \\
(.0432)\end{array}$ & $\begin{array}{r}-.0624^{*} \\
(.0309)\end{array}$ & $\begin{array}{r}-.0561^{*} \\
(.0294)\end{array}$ \\
\hline \multicolumn{5}{|l|}{$F$-tests $/ \chi^{2}$ tests of parallel trends: } \\
\hline$\alpha_{2}=\beta_{2}=\gamma_{2}$ & $\begin{array}{l}.03 \\
{[.970]}\end{array}$ & $\begin{array}{l}.83 \\
{[.660]}\end{array}$ & $\begin{array}{l}1.37 \\
{[.270]}\end{array}$ & $\begin{array}{c}6.56^{* *} \\
{[.038]}\end{array}$ \\
\hline$\alpha_{1}=\beta_{1}=\gamma_{1}$ & $\begin{array}{l}.04 \\
{[.962]}\end{array}$ & $\begin{array}{l}.53 \\
{[.765]}\end{array}$ & $\begin{array}{l}2.33 \\
{[.114]}\end{array}$ & $\begin{array}{c}8.95 * * \\
{[.011]}\end{array}$ \\
\hline $\begin{array}{l}\text { Intrahousehold spillovers: } \\
\quad\left(\alpha_{1}-\alpha_{2}\right)-\left(\gamma_{1}-\gamma_{2}\right)\end{array}$ & $\begin{array}{l}.0046 \\
(.0554)\end{array}$ & $\begin{array}{r}-.0027 \\
(.0645)\end{array}$ & $\begin{array}{l}.0694 \\
(.421)\end{array}$ & $\begin{array}{l}.0965 \\
(.0603)\end{array}$ \\
\hline $\begin{array}{l}\text { Intravillage spillovers: } \\
\qquad\left(\beta_{1}-\beta_{2}\right)-\left(\gamma_{1}-\gamma_{2}\right)\end{array}$ & $\begin{array}{c}.0286 \\
(.0555)\end{array}$ & $\begin{array}{c}.0511 \\
(.0484)\end{array}$ & $\begin{array}{c}.0271 \\
(.0480)\end{array}$ & $\begin{array}{l}.0360 \\
(.0531)\end{array}$ \\
\hline $\begin{array}{l}\text { Program impact including } \\
\text { intrahousehold spillovers: } \\
\tau+\left(\alpha_{1}-\alpha_{2}\right)-\left(\gamma_{1}-\gamma_{2}\right)\end{array}$ & $\begin{array}{l}.1371 * * \\
(.0581)\end{array}$ & $\begin{array}{l}.1621 * * \\
(.0642)\end{array}$ & $\begin{array}{l}.1854 * * * \\
(.0425)\end{array}$ & $\begin{array}{l}.1589 * * * \\
(.0503)\end{array}$ \\
\hline Hausman test $[p$-value $]$ & $\ldots$ & {$[.959]$} & $\ldots$ & {$[.785]$} \\
\hline Overidentification $(J$-test $)[p$-value $]$ & $\ldots$ & $\begin{array}{l}6.18 \\
{[.519]}\end{array}$ & $\ldots$ & $\begin{array}{l}6.85 \\
{[.444]}\end{array}$ \\
\hline Weak IV test ( $F$-statistic) & . & 60.03 & & 48.93 \\
\hline Observations & 9,954 & 9,954 & 9,954 & 9,954 \\
\hline$R^{2}$ & .164 & .161 & .033 & .019 \\
\hline
\end{tabular}

NoTE.-Clustered standard errors at the village level are in parentheses. Each regression includes controls for age at program introduction (ACI) at age 12 and below and at ages 13-16, age, age squared, birth order, gender, status as oldest child, mother's education, father's education, mother's education missing, and father's education missing.

* Significant at 10 percent.

** Significant at 5 percent.

*** Significant at 1 percent. 
to examine. OLS estimates (col. 1) indicate that the direct effect of the program $(\tau)$ raises the probability of completing secondary school by 13.2 percentage points. The IV estimates (col. 2) show a 16.5 percentage point effect. Neither of these estimates shows significant spillover effects. Household fixed effects (cols. 3 and 4) yield marginally significant estimates of household spillovers onto other age-eligible siblings in secondary school completion, about 7 percentage points $(p$-value $=.109)$ in the OLS estimates and about 10 percentage points $(p$-value $=.110)$ in the IV estimates. (Another indication of spillovers is the rejection of parallel trends for individuals with $\mathrm{ACI} \leq 12$; $p$-value $=.011$.) Incorporating these estimated spillovers increases the full program effect to 18.5 percentage points (OLS-FE) and 15.9 percentage points (IV-GMMFE) on sponsored individuals, both of which are highly significant. The spillover point estimates, if valid, also indicate a $7-10$ percentage point impact on other age-eligible siblings.

Estimated impacts on completion of tertiary education are in table 9. OLS estimates with and without household fixed effects in columns 1 and 3 yield statistically significant direct impacts $(\tau)$ of 2.4 and 2.1 percentage points, respectively. Given a baseline completion rate of 4.3 percent, these point estimates, while small, reflect an approximate 50 percent increase over this baseline. The IV point estimates in columns 2 and 4 are somewhat larger but are of low statistical significance; moreover, Hausman tests cannot reject the consistency of the OLS estimates. Point estimates of intrahousehold spillovers are small but positive, such that the full impacts of the program (including spillovers) range from 3.2 to 5.1 percentage points, each significant at the 5 percent level. But owing to little direct evidence for household spillovers, we consider the more conservative estimates (on $\tau$ only) to be the best estimates of program impact. The IV-GMM estimate finds evidence of positive intravillage spillovers that is significant at the 5 percent level, but since this is the only significant evidence of such spillovers out of 16 estimates in tables $6-9$, it could simply reflect random chance. (At the 5 percent significance level one would expect one out of 20 estimates of a parameter that equals zero to be significantly different from zero.)

Table 10 presents estimated direct impacts $(\tau)$ separately for each of the six countries, focusing on the OLS and OLS with household fixedeffects estimates. ${ }^{12}$ While the program impacts are positive and statistically significant in each country, a striking feature of these estimates is the

\footnotetext{
${ }^{12}$ We omit country-specific IV estimates for space considerations and because Hausman tests never reject the consistency of the OLS estimates (with and without household fixed effects) in the combined sample. Also, the GMM-IV results are generally much less precise than the OLS estimates, and this imprecision is worsened by the small samples for each country. Finally, GMM-IV estimation requires the number of instruments to be less than the number of clusters (villages) to obtain estimates of clustered standard errors. This is not an issue for estimates that combine all six countries (which have 32 villages and use eight instruments), but for the individual countries we have only four to seven villages.
} 
TABLE 9

OLS And IV Estimates of Equations (1), $\left(2^{\prime}\right)$, (3), And $\left(4^{\prime}\right)$ : University Completion

\begin{tabular}{|c|c|c|c|c|}
\hline Variable & $\begin{array}{l}\text { OLS } \\
(1)\end{array}$ & $\begin{array}{l}\text { IV-GMM } \\
(2)\end{array}$ & $\begin{array}{l}\text { OLS-FE } \\
(3)\end{array}$ & $\begin{array}{l}\text { IV-GMM-FE } \\
(4)\end{array}$ \\
\hline Program participant $(\tau)$ & $\begin{array}{l}.0243^{* * *} \\
(.0090)\end{array}$ & $\begin{array}{l}.0356^{*} \\
(.0213)\end{array}$ & $\begin{array}{l}.0213 * * \\
(.0085)\end{array}$ & $\begin{array}{l}.0496 \\
(.0345)\end{array}$ \\
\hline \multicolumn{5}{|l|}{ Compassion household: } \\
\hline $\mathrm{ACI} \leq 12\left(\alpha_{1}\right)$ & $\begin{array}{c}.0164 \\
(.0139)\end{array}$ & $\begin{array}{l}.0085 \\
(.0113)\end{array}$ & $\begin{array}{l}.0331 * \\
(.0174)\end{array}$ & $\begin{array}{l}.0224 \\
(.0162)\end{array}$ \\
\hline ACI $13-16\left(\alpha_{2}\right)$ & $\begin{array}{l}.0094 \\
(.0117)\end{array}$ & $\begin{array}{l}.0038 \\
(.0099)\end{array}$ & $\begin{array}{l}.0150 \\
(.0129)\end{array}$ & $\begin{array}{l}.0137 \\
(.0123)\end{array}$ \\
\hline \multicolumn{5}{|l|}{ Program village: } \\
\hline $\mathrm{ACI} \leq 12\left(\beta_{1}\right)$ & $\begin{array}{l}.0300^{*} \\
(.0170)\end{array}$ & $\begin{array}{l}.0301 * * \\
(.0120)\end{array}$ & $\begin{array}{l}.0241 \\
(.0228)\end{array}$ & $\begin{array}{l}.0150 \\
(.0279)\end{array}$ \\
\hline ACI $13-16\left(\beta_{2}\right)$ & $\begin{array}{l}.0105 \\
(.0190)\end{array}$ & $\begin{array}{l}.0060 \\
(.0120)\end{array}$ & $\begin{array}{c}.0131 \\
(.0183)\end{array}$ & $\begin{array}{l}.0044 \\
(.0193)\end{array}$ \\
\hline \multicolumn{5}{|l|}{ Nonprogram village: } \\
\hline $\mathrm{ACI} \leq 12\left(\gamma_{1}\right)$ & $\begin{array}{r}-.0036 \\
(.0161)\end{array}$ & $\begin{array}{r}-.0010 \\
(.0142)\end{array}$ & $\begin{array}{l}.0021 \\
(.0199)\end{array}$ & $\begin{array}{l}.0006 \\
(.0189)\end{array}$ \\
\hline ACI $13-16\left(\gamma_{2}\right)$ & $\begin{array}{c}-.0031 \\
(.0163)\end{array}$ & $\begin{array}{l}.0001 \\
(.0147)\end{array}$ & $\begin{array}{r}-.0069 \\
(.0114)\end{array}$ & $\begin{aligned}-.0065 \\
(.0111)\end{aligned}$ \\
\hline \multicolumn{5}{|l|}{$F$-tests $/ \chi^{2}$ tests of parallel trends: } \\
\hline$\alpha_{2}=\beta_{2}=\gamma_{2}$ & $\begin{array}{l}.24 \\
{[.786]}\end{array}$ & $\begin{array}{l}.11 \\
{[.948]}\end{array}$ & $\begin{array}{l}1.17 \\
{[.324]}\end{array}$ & $\begin{array}{l}1.99 \\
{[.370]}\end{array}$ \\
\hline$\alpha_{1}=\beta_{1}=\gamma_{1}$ & $\begin{array}{l}1.60 \\
{[.218]}\end{array}$ & $\begin{array}{c}8.23 * * \\
{[.016]}\end{array}$ & $\begin{array}{l}1.07 \\
{[.356]}\end{array}$ & {$[.96$} \\
\hline $\begin{array}{l}\text { Intrahousehold spillovers: } \\
\qquad\left(\alpha_{1}-\alpha_{2}\right)-\left(\gamma_{1}-\gamma_{2}\right) \\
\text { Intravillage spillovers: }\end{array}$ & $\begin{array}{l}.0075 \\
(.0128)\end{array}$ & $\begin{array}{l}.0058 \\
(.0125)\end{array}$ & $\begin{array}{l}.0091 \\
(.0126)\end{array}$ & $\begin{array}{l}.0015 \\
(.0164)\end{array}$ \\
\hline $\begin{array}{l}\text { Intravillage spillovers: } \\
\qquad\left(\beta_{1}-\beta_{2}\right)-\left(\gamma_{1}-\gamma_{2}\right)\end{array}$ & $\begin{array}{c}.0200 \\
(.0145)\end{array}$ & $\begin{array}{l}.0252 * * \\
(.0119)\end{array}$ & $\begin{array}{c}.0020 \\
(.0206)\end{array}$ & $\begin{array}{l}.0035 \\
(.0207)\end{array}$ \\
\hline $\begin{array}{l}\text { Program impact including } \\
\text { intrahousehold spillovers: } \\
\tau+\left(\alpha_{1}-\alpha_{2}\right)-\left(\gamma_{1}-\gamma_{2}\right)\end{array}$ & $\begin{array}{l}.0318 * * \\
(.0137)\end{array}$ & $\begin{array}{l}.0414^{* * *} \\
(.0178)\end{array}$ & $\begin{array}{l}.0304 * * \\
(.0149)\end{array}$ & $\begin{array}{l}.0511 * * \\
(.0247)\end{array}$ \\
\hline Hausman test [ $p$-value $]$ & $\ldots$ & {$[.625]$} & $\ldots$ & {$[.304]$} \\
\hline Overidentification $(J$-test $)[p$-value $]$ & $\cdots$ & $\begin{array}{l}9.45 \\
{[.222]}\end{array}$ & $\cdots$ & $\begin{array}{l}2.73 \\
{[.909]}\end{array}$ \\
\hline Weak IV test ( $F$-statistic) & $\therefore$ & 60.03 & $\ldots$ & 48.93 \\
\hline Observations & 9,954 & 9,954 & 9,954 & 9,954 \\
\hline$R^{2}$ & .021 & .020 & .012 & .006 \\
\hline
\end{tabular}

Note.-Clustered standard errors at the village level are in parentheses. Each regression includes controls for age at program introduction (ACI) at age 12 and below and at ages 13-16, age, age squared, birth order, gender, status as oldest child, mother's education, father's education, mother's education missing, and father's education missing.

* Significant at 10 percent.

** Significant at 5 percent.

*** Significant at 1 percent.

variation across countries. The estimated impacts of sponsorship are highest in Uganda: the OLS estimates are 2.47 more years of schooling, a 10.6 percentage point increase in primary school completion, and 25.3 and 7.7 percentage point increases for secondary and university completion, respectively (household fixed-effect estimates are quite similar). The second-highest impacts are most often found for Kenya, where point 
TABLE 10

OLS and OLS Household Fixed-Effect Estimates for Education by Country

\begin{tabular}{|c|c|c|c|c|c|c|}
\hline \multirow[t]{2}{*}{ Variable } & Uganda & Guatemala & Philippines & India & Kenya & Bolivia \\
\hline & \multicolumn{6}{|c|}{ Total Years of Education } \\
\hline \multirow{2}{*}{\multicolumn{7}{|c|}{ Program participant $(\tau)}}$, \\
\hline & $2.472 * * *$ & $.528 * * *$ & $.573 * * *$ & $.658 * *$ & $1.156^{* * *}$ & $.668 * *$ \\
\hline & $(.236)$ & (.113) & $(.064)$ & $(.226)$ & $(.142)$ & $(.184)$ \\
\hline$R^{2}$ & .332 & .426 & .213 & .246 & .156 & .307 \\
\hline \multicolumn{7}{|l|}{ Program participant $(\tau)$} \\
\hline household fixed effects & $2.216 * * *$ & $.830 * * *$ & $.631 * * *$ & $.768 * *$ & $1.312 * * *$ & $.733^{* *}$ \\
\hline & $(.232)$ & $(.166)$ & $(.008)$ & $(.171)$ & $(.141)$ & $(.228)$ \\
\hline$R^{2}$ & .127 & .147 & .114 & .062 & .075 & .128 \\
\hline \multirow[t]{2}{*}{ Baseline, untreated } & 8.37 & 8.12 & 12.11 & 11.45 & 10.22 & 10.32 \\
\hline & \multicolumn{6}{|c|}{ Primary Completion } \\
\hline \multirow{2}{*}{\multicolumn{7}{|c|}{$\begin{array}{l}\text { Program participant }(\tau), \\
\text { OLS }\end{array}$}} \\
\hline & $.1061 * *$ & $-.0112 *$ & .0030 & $.0298 *$ & $.0334 *$ & .0380 \\
\hline & $(.0283)$ & $(.0048)$ & $(.0016)$ & $(.0115)$ & $(.0152)$ & $(.0299)$ \\
\hline$R^{2}$ & .206 & .329 & .060 & .093 & .036 & .231 \\
\hline \multicolumn{7}{|c|}{ Program participant $(\tau)$} \\
\hline household fixed effects & $.0966^{* *}$ & $.0270^{*}$ & .0054 & $.0293 *$ & $.0517 * *$ & .0491 \\
\hline & $(.0339)$ & $(.0116)$ & $(.0028)$ & $(.0128)$ & $(.0162)$ & $(.0313)$ \\
\hline$R^{2}$ & .076 & .120 & .009 & .027 & .014 & .170 \\
\hline \multirow[t]{2}{*}{ Baseline, untreated } & .795 & .744 & .993 & .926 & .948 & .816 \\
\hline & \multicolumn{6}{|c|}{ Secondary Completion } \\
\hline \multirow{3}{*}{$\begin{array}{l}\text { Program participant }(\tau), \\
\text { OLS }\end{array}$} & & & & & & \\
\hline & $.2532 * *$ & $.1403^{* * *}$ & $.1173^{* * * *}$ & .0833 & $.1218 * * *$ & .0134 \\
\hline & $(.0568)$ & $(.0106)$ & $(.0176)$ & $(.0455)$ & $(.0207)$ & $(.0144)$ \\
\hline$R^{2}$ & .196 & .293 & .151 & .195 & .095 & .204 \\
\hline \multicolumn{7}{|l|}{ Program participant $(\tau)$} \\
\hline \multirow[t]{2}{*}{ household fixed effects } & $.2176^{* *}$ & $.1320 * * *$ & $.1203^{* * * *}$ & .0869 & $.1154 * *$ & .0259 \\
\hline & $(.0580)$ & $(.0206)$ & $(.0026)$ & $(.0464)$ & $(.0345)$ & $(.0235)$ \\
\hline$R^{2}$ & .075 & .099 & .060 & .039 & .037 & .052 \\
\hline \multirow[t]{2}{*}{ Baseline, untreated } & .192 & .406 & .732 & .568 & .314 & .503 \\
\hline & \multicolumn{6}{|c|}{ University Completion } \\
\hline \multirow{3}{*}{$\begin{array}{l}\text { Program participant }(\tau), \\
\text { OLS }\end{array}$} & & & & & & \\
\hline & $.0771 * *$ & .0079 & .0023 & .0010 & .0109 & $.0509 *$ \\
\hline & $(.0188)$ & $(.0207)$ & $(.0089)$ & $(.0290)$ & $(.0106)$ & $(.0245)$ \\
\hline$R^{2}$ & .107 & .063 & .024 & .050 & .058 & .083 \\
\hline \multicolumn{7}{|l|}{ Program participant $(\tau)$} \\
\hline household fixed effects & $.0780 * * *$ & .0205 & .0071 & -.0021 & .0056 & $.0531 *$ \\
\hline & $(.0154)$ & $(.0111)$ & $(.0088)$ & $(.0242)$ & $(.0052)$ & $(.0218)$ \\
\hline$R^{2}$ & .037 & .030 & .045 & .015 & .015 & .036 \\
\hline Baseline, untreated & .055 & .016 & .020 & .042 & .037 & .102 \\
\hline Observations & 809 & 1,656 & 1,390 & 1,591 & 3,050 & 1,458 \\
\hline
\end{tabular}

NoтE.-Clustered standard errors at the village level are in parentheses. Each regression includes controls for age at program introduction (ACI) at age 12 and below and at ages 13-16, age, age squared, birth order, gender, status as oldest child, mother's education, father's education, mother's education missing, and father's education missing.

* Significant at 10 percent.

** Significant at 5 percent.

*** Significant at 1 percent. 
estimates are 1.16 years for formal schooling, with impacts (in percentage points) of 3.3 for primary completion, 12.2 for secondary completion, but no significant impact for university completion. Guatemala and the Philippines have high estimated impacts for secondary school completion, at 14.0 and 11.7 percentage points, respectively. In Bolivia, nearly all of the significant impact occurs at the university level, where sponsored individuals are 5.1 percentage points more likely to acquire a university education. In India, impacts are smaller and are confined to the lower levels of education. Overall the magnitude of educational impacts across educational levels is much higher in the African countries than in the Latin American and Asian countries. Thus, the impact of child sponsorship appears to be greatest where counterfactual levels of education are lowest: Kenya and Uganda have the lowest rates of secondary school completion and are second and third lowest in terms of years of completed schooling among the six countries in our data.

Table 11 shows estimated impacts on total years of formal schooling by country and by gender, based on the OLS fixed-effect specification (OLS estimates without fixed effects are very similar). The most striking feature of these results is that the impacts are generally larger for the gender with the lowest baseline education levels. In particular, in the Phil-

TABLE 11

OLS Fixed-Effect Estimates for Total Years of Schooling By Country and Gender

\begin{tabular}{|c|c|c|c|c|c|c|}
\hline Variable & Uganda & Guatemala & Philippines & India & Kenya & Bolivia \\
\hline & \multicolumn{6}{|c|}{ Boys } \\
\hline $\begin{array}{l}\text { Program } \\
\quad \text { participant }(\tau)\end{array}$ & $\begin{array}{l}1.463^{* *} \\
(.518)\end{array}$ & $\begin{array}{l}.496 \\
(.361)\end{array}$ & $\begin{array}{l}.706^{* * * *} \\
(.041)\end{array}$ & $\begin{array}{l}.671 * * \\
(.229)\end{array}$ & $\begin{array}{l}1.486 * * * \\
(.189)\end{array}$ & $\begin{array}{l}.481 * * * \\
(.104)\end{array}$ \\
\hline $\begin{array}{l}\text { Observations } \\
R^{2}\end{array}$ & $\begin{array}{c}385 \\
.169\end{array}$ & $\begin{array}{c}848 \\
.141\end{array}$ & $\begin{array}{r}697 \\
.071\end{array}$ & $\begin{array}{l}795 \\
.064\end{array}$ & $\begin{array}{l}1,569 \\
.069\end{array}$ & $\begin{array}{r}730 \\
.134\end{array}$ \\
\hline \multirow{2}{*}{$\begin{array}{l}\text { Baseline, } \\
\text { untreated }\end{array}$} & 8.39 & 8.48 & 11.86 & 11.24 & 10.29 & 10.55 \\
\hline & \multicolumn{6}{|c|}{ Girls } \\
\hline $\begin{array}{l}\text { Program } \\
\quad \text { participant }(\tau)\end{array}$ & $\begin{array}{l}2.735^{* * * *} \\
(.405)\end{array}$ & $\begin{array}{l}1.190 * * * \\
(.173)\end{array}$ & $\begin{array}{l}.395 * * * \\
(.053)\end{array}$ & $\begin{array}{l}.423 \\
(.328)\end{array}$ & $\begin{array}{l}.935^{* * *} \\
(.124)\end{array}$ & $\begin{array}{l}.695 \\
(.517)\end{array}$ \\
\hline $\begin{array}{l}\text { Observations } \\
R^{2}\end{array}$ & $\begin{array}{c}424 \\
.163\end{array}$ & $\begin{array}{c}808 \\
.214\end{array}$ & $\begin{array}{r}693 \\
.154\end{array}$ & $\begin{array}{l}796 \\
.110\end{array}$ & $\begin{array}{l}1,481 \\
.081\end{array}$ & $\begin{array}{r}728 \\
.165\end{array}$ \\
\hline $\begin{array}{l}\text { Baseline, } \\
\text { untreated }\end{array}$ & 8.35 & 7.74 & 12.37 & 11.66 & 10.14 & 10.08 \\
\hline
\end{tabular}

NoтE.-Estimations include fixed effects at the household level. Clustered standard errors at the village level are in parentheses. Each regression includes controls for age at program introduction (ACI) at age 12 and below and at ages 13-16, age, age squared, birth order, gender, and status as oldest child.

* Significant at 10 percent.

** Significant at 5 percent.

*** Significant at 1 percent. 
ippines and India, where baseline schooling is higher for girls among nonsponsored children, the impact of sponsorship is higher for boys. Similarly, in Uganda, Guatemala, and Bolivia, where baseline schooling is higher for boys among nonsponsored children, point estimates of program impact are higher for girls.

\section{B. Impacts on Employment and Leadership}

Along with educational goals, two other major objectives of the Compassion program are to prepare sponsored children for employment and community leadership. We briefly discuss program impacts on these outcomes; the estimates are given in the Appendix. Two employment outcomes are considered: (1) the probability of formal employment, defined as "currently employed at a steady salary," which rules out itinerant laborer work; and (2) the probability of "white-collar" employment. ${ }^{13} \mathrm{Ta}-$ ble A1 presents basic descriptive statistics for the employment and leadership variables. OLS (OLS with fixed effects) estimates in table A2 show a significant direct impact $(\tau)$ of 5.1 (6.3) percentage points over a 35.9 percent baseline level of formal employment. The IV-GMM estimates of $\tau$ are much larger, but the full impact estimates that adjust for negative spillovers (which may reflect an inelastic supply of salaried jobs in the local community) are closer to the OLS and OLS-FE estimates. OLS estimates for white-collar employment in table A3 show impacts of 6.5 and 6.7 percentage points over a baseline of 18.7 percent. Multinomial logit estimates of program impacts on movement into the different job categories in table A4 show that the increase in white-collar work is not from a large movement into high-paying jobs; it primarily consists of movement toward relatively modestly paid white-collar work, particularly teaching. With a 3.4 percentage point marginal effect and a baseline level of 5.4 percent, Compassion sponsorship increases the probability that a child becomes a teacher by 63 percent. The reason may be that many Compassion children are from families with little exposure to white-collar work, so that teachers may serve as primary role models. Individual country estimations in table A7 show that employment impacts tend to be highest in countries where economic growth is higher, specifically in the Philippines, India, and Guatemala.

A third Compassion goal is to develop leadership skills. OLS and fixedeffects OLS estimates yield impacts of 2.2 to 0.9 percentage points, respectively, on the probability of being a community leader in adulthood

\footnotetext{
${ }^{13}$ We divided occupations into 14 types: (1) agriculture, (2) construction, (3) clerical/ sales, (4) blue-collar work, (5) personal services, (6) teaching, (7) public administration, (8) small business, (9) pastoral/religious ministry, (10) finance/large business, (11) police/ army/security, (12) professional (doctors, lawyers, engineers, etc.), (13) less skilled technical work (e.g., call centers), and (14) nursing/public health. A "white-collar" job is defined as categories $3,6,7,9,10$, and $12-14$.
} 
over a baseline of 2.9 percent, but IV estimations are near zero or even negative (table A5). OLS and OLS with fixed-effects estimates (table A6) yield 6.0 and 3.5 percentage point increases, respectively, on the probability of becoming a church leader over an 8.7 percent baseline, while IV estimations are negative and imprecisely estimated.

\section{Robustness Checks}

We conducted a number of robustness checks on these results. Estimates that limit the sample to those over age 25 yield similar point estimates and significance for the education (and employment) outcomes. We also tried several different sets of instruments, interacting our instrumental variables with three other variables to obtain ACI group $\otimes S O R R \times$ gender, ACI group $\otimes$ SORR $\times$ age, and ACI group $\otimes$ SORR $\times$ birth order. Some of these instruments offered higher first-stage $F$-statistics, others slightly lower. Results from using different instruments yield nearly identical estimates for the educational outcomes. Some instrument sets yielded slightly larger and more significant impacts on employment and leadership outcomes, while others were slightly weaker. Overall, our chosen instrument set is in about the middle of all the instrument sets we tried in terms of both first- and second-stage significance, and thus it provides reasonably stable estimates of the impact of the Compassion program.

A third robustness check verified that the estimated impacts do not reflect negative spillovers onto older siblings. Estimates for the education (and employment) variables on sponsored children who had no older siblings yield coefficients that are generally similar to those provided here. We also considered the possibility of reporting bias that favored the program. To avoid this bias, the enumerators had no formal ties to the sponsorship program. We also find no evidence of reporting bias; separate regressions for each type of principal respondent (parent, sponsored child, sibling, etc.) yield essentially no differences in point estimates or significance of estimated impacts. Finally, although we found 93.5 percent of the families of the formerly sponsored children, could the results be significantly different for the 6.5 percent whom we were unable to locate? This is unlikely since the strongest results are for the two African countries, where we located 99 percent of the formerly sponsored children's families.

\section{Conclusion}

We estimate that the Compassion child sponsorship program increases years of completed schooling by 1.03-1.46 years over a baseline of 10.19 years and increases the probability of primary school completion by $4.0-7.7$ percentage points (baseline 88.7 percent), secondary school completion by $11.6-16.5$ percentage points (baseline 44.9 percent), and 
university completion by 2.1-2.4 percentage points (baseline 4.3 percent). We also find impacts of 5.1-6.3 percentage points on the probability of salaried employment in adulthood and a 6.5-6.7 percentage point increase in the probability of white-collar employment, as well as modest evidence for causal impacts on community and church leadership.

One can compare these estimated impacts of Compassion's child sponsorship program on education outcomes to recent estimates for other educational interventions. For example, Aaronson and Mazumder (2011) examine the introduction of Rosenwald schools from 1913 to 1931 to foster the education among rural blacks in the US South. They conclude that the introduction of these schools increased secondary school completion among rural blacks by 8.3 percentage points and increased formal schooling outcomes by 1.2 years, estimates that are strikingly similar to ours. Our results for the Compassion program compare favorably to the 0.66-year increase in years of schooling found by Schultz (2004) on the PROGRESA/Oportunidades CCT program in Mexico and the 0.12-0.19 increase in years of schooling that Duflo (2001) estimates as the impact of the large school construction program in Indonesia; she also estimates a 6 percentage point increase in primary school completion, an estimate similar to ours, but finds a slightly negative impact on secondary completion.

We conclude by discussing a possible causal mechanism behind these impacts that subsequent work has begun to explore. The most salient characteristic that distinguishes Compassion's program from comparable interventions is its emphasis on raising children's self-esteem, reference points, and aspirations. As such, it aims to simultaneously relieve both internal and external constraints that can impede progress in education. ${ }^{14}$ Indeed, the role of psychological factors has gained increasing attention in development economics. ${ }^{15}$ Recent research has explored the role of psychological factors on credit decisions (Bertrand et al. 2010), health (Dupas 2010), technology adoption (Duflo, Kremer, and Robinson 2011), and education (Kremer et al. 2009).

Three follow-up studies conducted in Bolivia, Kenya, and Indonesia investigate whether adult life outcomes may have been shaped by the Compassion program's focus on developing self-esteem and nurturing aspirations during childhood. Unlike this paper, which examines for-

\footnotetext{
${ }^{14}$ Dalton et al. (2010) provide an excellent theoretical treatment of internalized poverty constraints.

${ }^{15}$ Mullainathan (2006) and Bernard et al. (2011) review the role of psychology in development economics.
} 
merly sponsored subjects who are now adults, these three follow-up studies focus on currently sponsored children.

Ross (2010) examines the life aspirations of 270 children living near Compassion sponsorship projects in Bolivia. In response to the question, "What level of education would you say is sufficient for one to be successful today?" sponsored children's answers yield village fixed-effect estimates averaging 0.89 year higher than unsponsored children (average $p<.05$ ), a figure just under the estimated impact on years of schooling found in this paper. Sponsored children also appear to have higher self-expectations for future vocations. When asked "What occupation do you realistically expect to have in the future?" sponsored children were 10.1-25.3 percentage points more likely than unsponsored children to respond with a white-collar occupation (average $p<.10$ ).

In a second follow-up study, Ross and Wydick (2011) surveyed 570 children aged 10-18 in three villages in Kenya, using an IV strategy that exploits the same age eligibility and limited children per family sponsorship rules used in this paper. Estimates indicate that sponsorship raises educational expectations by 0.23 standard deviations of the distribution of those expectations $(p<.10)$, as well as raising the probability that a child expects to have a white-collar job by 12.5 percentage points. These changes in expectations about future education and vocation are similar to the estimated impacts among the adults found in this paper.

A third follow-up study, Glewwe and Wydick (2013), examines data from 540 poor children in the slums of Jakarta, Indonesia, finding impacts on schooling aspirations from sponsorship that parallel the findings of the previous two studies. In addition, a new box of 24 colored pencils was placed in front of each child, who was then asked to "draw a picture of yourself in the rain." Using factor analysis with a varimax rotation on 20 dummy variables that relate drawing characteristics to five measures of hopefulness and self-esteem, we were able to identify three latent factors: happiness, self-efficacy, and hopelessness. ${ }^{16}$ Regressions controlling for age, gender, family selection, and neighborhood reveal a 0.27 standard deviation increase in happiness among the Compassionsponsored children $(t=2.40)$, a 0.33 standard deviation increase in selfefficacy $(t=3.11)$, and a 0.52 standard deviation decrease in hopelessness $(t=5.19)$.

${ }^{16}$ There is a large literature on interpreting children's drawings to gauge their psychological well-being (Koppitz 1968; Klepsch and Logie 1982; Furth 2002). Researchers have found empirical correlations between aspects of children's human figure drawings to a variety of professionally diagnosed disorders, including anxiety and emotional insecurity (missing mouth, frowning, use of dark colors), low self-esteem (tiny figure, poor integration of body parts, missing arms or hands), and low self-efficacy (tiny head, short arms). 
While further work is required to establish a causal link between aspirations and adult life outcomes, the possibility that nurturing aspirations can have important effects on economic development has intriguing implications. Traditionally, development economics - and indeed the practice of economic development-has focused on the relief of external constraints such as school quality, infrastructure, and credit. But it may be that the internal constraints of the poor also contribute to poverty traps in important ways. Further observational and experimental research should seek to better understand the internal constraints faced by the poor and how development efforts that seek to release internal constraints can complement purely economic interventions and incentives.

\section{Appendix}

TABLE A1

Summary Means and $t$-Tests of Employment and Leadership Variables

\begin{tabular}{|c|c|c|c|c|c|}
\hline & $\begin{array}{c}\text { Mean, } \\
\text { Sponsored } \\
\text { Individuals } \\
(1) \\
\end{array}$ & $\begin{array}{c}\text { Mean, All } \\
\text { Nonsponsored } \\
\text { Individuals } \\
(2) \\
\end{array}$ & $\begin{array}{c}\text { Difference } \\
t \text {-Test } \\
(3) \\
\end{array}$ & $\begin{array}{l}\text { Mean, Non- } \\
\text { sponsored } \\
\text { Siblings in } \\
\text { Sponsored } \\
\text { Households } \\
\quad(4)\end{array}$ & $\begin{array}{c}\text { Difference } \\
t \text {-Test } \\
(5) \\
\end{array}$ \\
\hline Formally employed & $\begin{array}{l}.423 \\
(.494)\end{array}$ & $\begin{array}{l}.359 \\
(.480)\end{array}$ & $\begin{array}{l}.064 * * * \\
(.013)\end{array}$ & $\begin{array}{l}.341 \\
(.474)\end{array}$ & $\begin{array}{l}.082 * * * \\
(.014)\end{array}$ \\
\hline White-collar employed & $\begin{array}{l}.274 \\
(.446)\end{array}$ & $\begin{array}{l}.187 \\
(.390)\end{array}$ & $\begin{array}{l}.086^{* * *} \\
(.011)\end{array}$ & $\begin{array}{l}.180 \\
(.384)\end{array}$ & $\begin{array}{l}.094 * * * \\
(.012)\end{array}$ \\
\hline Community leader & $\begin{array}{l}.046 \\
(.209)\end{array}$ & $\begin{array}{l}.029 \\
(.168)\end{array}$ & $\begin{array}{l}.017 * * * \\
(.0047)\end{array}$ & $\begin{array}{l}.026 \\
(.159)\end{array}$ & $\begin{array}{l}.020 * * * \\
(.005)\end{array}$ \\
\hline Church leader & $\begin{array}{l}.161 \\
(.367)\end{array}$ & $\begin{array}{l}.087 \\
(.282)\end{array}$ & $\begin{array}{l}.073 * * * \\
(.0079)\end{array}$ & $\begin{array}{l}.095 \\
(.293)\end{array}$ & $\begin{array}{l}.065 * * * \\
(.0094)\end{array}$ \\
\hline
\end{tabular}

Note.--In cols. 1, 2, and 4, numbers in parentheses are standard deviations. In cols. 3 and 5, numbers in parentheses are standard errors. Full sample size is 10,144. Number of formerly sponsored individuals is 1,860 . Number of individuals in nontreated households is 4,580 . Number of nonsponsored individuals in treated households is 3,704.

* Significant at 10 percent.

** Significant at 5 percent.

*** Significant at 1 percent. 
TABLE A2

OLS And IV Estimates of Equations (1), $\left(2^{\prime}\right)$, (3), and $\left(4^{\prime}\right)$ : Formal Employment

\begin{tabular}{|c|c|c|c|c|}
\hline Variable & $\begin{array}{l}\text { OLS } \\
(1)\end{array}$ & $\begin{array}{l}\text { IV-GMM } \\
(2)\end{array}$ & $\begin{array}{l}\text { OLS-FE } \\
(3)\end{array}$ & $\begin{array}{l}\text { IV-GMM-FE } \\
(4)\end{array}$ \\
\hline Program participant $(\tau)$ & $\begin{array}{l}.0505^{*} \\
(.0264)\end{array}$ & $\begin{array}{l}.1869 * * * \\
(.0667)\end{array}$ & $\begin{array}{l}.0628 * * * \\
(.0148)\end{array}$ & $\begin{array}{l}.2888 * * * \\
(.0712)\end{array}$ \\
\hline \multicolumn{5}{|l|}{ Compassion household: } \\
\hline $\mathrm{ACI} \leq 12\left(\alpha_{1}\right)$ & $\begin{array}{l}.1399 \\
(.0887)\end{array}$ & $\begin{array}{l}.0405 \\
(.0698)\end{array}$ & $\begin{array}{l}.1149 * * * \\
(.0387)\end{array}$ & $\begin{array}{l}.0009 \\
(.0451)\end{array}$ \\
\hline ACI $13-16\left(\alpha_{2}\right)$ & $\begin{array}{l}.0425 \\
(.0542)\end{array}$ & $\begin{array}{l}.0434 \\
(.0406)\end{array}$ & $\begin{array}{l}.0458 \\
(.0313)\end{array}$ & $\begin{array}{l}.0368 \\
(.0230)\end{array}$ \\
\hline \multicolumn{5}{|l|}{ Program village: } \\
\hline $\mathrm{ACI} \leq 12\left(\beta_{1}\right)$ & $\begin{array}{l}.1197 \\
(.0992)\end{array}$ & $\begin{array}{l}.0822 \\
(.0621)\end{array}$ & $\begin{array}{l}.1517 * * * \\
(.0412)\end{array}$ & $\begin{array}{l}.1521 * * * \\
(.0368)\end{array}$ \\
\hline ACI $13-16\left(\beta_{2}\right)$ & $\begin{array}{l}.1021 \\
(.0688)\end{array}$ & $\begin{array}{l}.0859 * * \\
(.0427)\end{array}$ & $\begin{array}{l}.1078^{* *} \\
(.0466)\end{array}$ & $\begin{array}{l}.1230 * * * \\
(.0387)\end{array}$ \\
\hline \multicolumn{5}{|l|}{ Nonprogram village: } \\
\hline $\mathrm{ACI} \leq 12\left(\gamma_{1}\right)$ & $\begin{array}{r}-.0169 \\
(.1002)\end{array}$ & $\begin{array}{r}-.0385 \\
(.0710)\end{array}$ & $\begin{array}{l}.0867 \\
(.0646)\end{array}$ & $\begin{array}{l}.0889 \\
(.0608)\end{array}$ \\
\hline ACI $13-16\left(\gamma_{2}\right)$ & $\begin{array}{r}-.1111^{*} \\
(.0582)\end{array}$ & $\begin{array}{l}-.1235^{* * * *} \\
(.0421)\end{array}$ & $\begin{array}{c}-.0261 \\
(.0497)\end{array}$ & $\begin{array}{r}-.0208 \\
(.0481)\end{array}$ \\
\hline \multicolumn{5}{|l|}{$F$-tests $/ \chi^{2}$ tests of parallel trends: } \\
\hline$\alpha_{2}=\beta_{2}=\gamma_{2}$ & $\begin{array}{l}9.23 * * * \\
{[.001]}\end{array}$ & $\begin{array}{l}23.06 * * * \\
{[.000]}\end{array}$ & $\begin{array}{l}2.40 \\
{[.108]}\end{array}$ & $\begin{array}{l}7.05 * * \\
{[.030]}\end{array}$ \\
\hline$\alpha_{1}=\beta_{1}=\gamma_{1}$ & $\begin{array}{l}3.02 * \\
{[.063]}\end{array}$ & $\begin{array}{l}2.91 \\
{[.234]}\end{array}$ & $\begin{array}{l}.66 \\
{[.522]}\end{array}$ & $\begin{array}{c}11.89 * * * \\
.003\end{array}$ \\
\hline $\begin{array}{l}\text { Intrahousehold spillovers: } \\
\qquad\left(\alpha_{1}-\alpha_{2}\right)-\left(\gamma_{1}-\gamma_{2}\right) \\
\text { Intravillage spillovers. }\end{array}$ & $\begin{array}{l}.0033 \\
(.0458)\end{array}$ & $\begin{array}{r}-.0879 * \\
(.0477)\end{array}$ & $\begin{array}{r}-.0436 \\
(.0370)\end{array}$ & $\begin{array}{l}-.1456^{* * * *} \\
(.0480)\end{array}$ \\
\hline $\begin{array}{l}\text { Intravillage spillovers: } \\
\qquad\left(\beta_{1}-\beta_{2}\right)-\left(\gamma_{1}-\gamma_{2}\right)\end{array}$ & $\begin{array}{c}-.0765 \\
(.0583)\end{array}$ & $\begin{array}{c}-.0886^{*} \\
(.0463)\end{array}$ & $\begin{array}{c}-.0688 \\
(.0466)\end{array}$ & $\begin{array}{c}-.0807 * * \\
(.0381)\end{array}$ \\
\hline $\begin{array}{l}\text { Program impact including } \\
\text { intrahousehold spillovers: } \\
\tau+\left(\alpha_{1}-\alpha_{2}\right)-\left(\gamma_{1}-\gamma_{2}\right)\end{array}$ & $\begin{array}{l}.0538 \\
(.0545)\end{array}$ & $\begin{array}{c}.0990 * \\
(.0557)\end{array}$ & $\begin{array}{c}.0192 \\
(.0384)\end{array}$ & $\begin{array}{l}.1431 * * * \\
(.0467)\end{array}$ \\
\hline Hausman test [ $p$-value] & $\ldots$ & {$[.255]$} & $\ldots$ & {$[.073]$} \\
\hline Overidentification ( $J$-test) $[p$-value $]$ & $\cdots$ & $\begin{array}{l}3.19 \\
{[.867]}\end{array}$ & $\cdots$ & $\begin{array}{l}7.86 \\
{[.447]}\end{array}$ \\
\hline Weak IV test ( $F$-statistic) & & 75.31 & & 50.09 \\
\hline Observations & 9,497 & 9,497 & 9,497 & 9,497 \\
\hline$R^{2}$ & .124 & .115 & .073 & .036 \\
\hline
\end{tabular}

NotE.-Clustered standard errors at the village level are in parentheses. Each regression includes controls for age at program introduction (ACI) at age 12 and below and at ages 13-16, age, age squared, birth order, gender, status as oldest child, mother's education, father's education, mother's education missing, and father's education missing.

* Significant at 10 percent.

** Significant at 5 percent.

*** Significant at 1 percent 
TABLE A3

OLS And IV Estimates of $(1),\left(2^{\prime}\right)$, (3), And $\left(4^{\prime}\right)$ : White-Collar Employment

\begin{tabular}{|c|c|c|c|c|}
\hline Variable & $\begin{array}{l}\text { OLS } \\
(1)\end{array}$ & $\begin{array}{l}\text { IV-GMM } \\
\quad(2)\end{array}$ & $\begin{array}{l}\text { OLS-FE } \\
(3)\end{array}$ & $\underset{(4)}{\text { IV-GMM-FE }}$ \\
\hline Program participant $(\tau)$ & $\begin{array}{l}.0654 * * * \\
(.0224)\end{array}$ & $\begin{array}{l}.0638 \\
(.0571)\end{array}$ & $\begin{array}{l}.0665^{* * * *} \\
(.0157)\end{array}$ & $\begin{array}{l}.0891 * \\
(.0509)\end{array}$ \\
\hline \multicolumn{5}{|l|}{ Compassion household: } \\
\hline $\mathrm{ACI} \leq 12\left(\alpha_{1}\right)$ & $\begin{array}{l}.0525 \\
(.0394)\end{array}$ & $\begin{array}{l}.0657 \\
(.0438)\end{array}$ & $\begin{array}{l}.0837 * * * \\
(.0301)\end{array}$ & $\begin{array}{l}.0870 * * \\
(.0384)\end{array}$ \\
\hline ACI $13-16\left(\alpha_{2}\right)$ & $\begin{array}{l}.0113 \\
(.0283)\end{array}$ & $\begin{array}{l}.0097 \\
(.0203)\end{array}$ & $\begin{array}{l}.0197 \\
(.0223)\end{array}$ & $\begin{array}{l}.0201 \\
(.0182)\end{array}$ \\
\hline \multicolumn{5}{|l|}{ Program village: } \\
\hline $\mathrm{ACI} \leq 12\left(\beta_{1}\right)$ & $\begin{array}{l}.1098^{* *} \\
(.0487)\end{array}$ & $\begin{array}{l}.1408 * * * \\
(.0300)\end{array}$ & $\begin{array}{l}.1167 * * \\
(.0447)\end{array}$ & $\begin{array}{l}.1252 * * * \\
(.0329)\end{array}$ \\
\hline ACI $13-16\left(\beta_{2}\right)$ & $\begin{array}{l}.0949 * * \\
(.0420)\end{array}$ & $\begin{array}{l}.0797 * * \\
(.0336)\end{array}$ & $\begin{array}{l}.1161^{* *} \\
(.0568)\end{array}$ & $\begin{array}{l}.1180^{* * * *} \\
(.0460)\end{array}$ \\
\hline \multicolumn{5}{|l|}{ Nonprogram village: } \\
\hline $\mathrm{ACI} \leq 12\left(\gamma_{1}\right)$ & $\begin{array}{c}.0167 \\
(.0591)\end{array}$ & $\begin{array}{l}.0633 \\
(.0457)\end{array}$ & $\begin{array}{l}.0694 \\
(.0452)\end{array}$ & $\begin{array}{l}.0931^{* *} \\
(.0423)\end{array}$ \\
\hline ACI $13-16\left(\gamma_{2}\right)$ & $\begin{array}{r}-.0204 \\
(.0496)\end{array}$ & $\begin{array}{l}.0165 \\
(.0423)\end{array}$ & $\begin{array}{l}.0017 \\
(.0414)\end{array}$ & $\begin{array}{l}.0311 \\
(.0392)\end{array}$ \\
\hline \multicolumn{5}{|l|}{$F$-tests $/ \chi^{2}$ tests of parallel trends: } \\
\hline$\alpha_{2}=\beta_{2}=\gamma_{2}$ & $\begin{array}{l}1.77 \\
{[.188]}\end{array}$ & $\begin{array}{l}2.69 \\
{[.261]}\end{array}$ & $\begin{array}{l}1.71 \\
{[.197]}\end{array}$ & $\begin{array}{l}5.09 * \\
{[.078]}\end{array}$ \\
\hline$\alpha_{1}=\beta_{1}=\gamma_{1}$ & $\begin{array}{l}2.87 * \\
{[.072]}\end{array}$ & $\begin{array}{c}7.29 * * \\
{[.026]}\end{array}$ & $\begin{array}{l}.43 \\
{[.657]}\end{array}$ & $\begin{array}{l}.89 \\
{[.640]}\end{array}$ \\
\hline $\begin{array}{l}\text { Intrahousehold spillovers: } \\
\quad\left(\alpha_{1}-\alpha_{2}\right)-\left(\gamma_{1}-\gamma_{2}\right)\end{array}$ & $\begin{array}{c}.0041 \\
(.0316)\end{array}$ & $\begin{array}{c}.0092 \\
(.0374)\end{array}$ & $\begin{array}{r}-.0037 \\
(.0230)\end{array}$ & $\begin{array}{c}.0050 \\
(.0362)\end{array}$ \\
\hline $\begin{array}{l}\text { Intravillage spillovers: } \\
\qquad\left(\beta_{1}-\beta_{2}\right)-\left(\gamma_{1}-\gamma_{2}\right)\end{array}$ & $\begin{array}{c}-.0221 \\
(.0503)\end{array}$ & $\begin{array}{c}.0143 \\
(.0420)\end{array}$ & $\begin{array}{r}-.0670 \\
(.0418)\end{array}$ & $\begin{array}{c}-.0547 * \\
(.0301)\end{array}$ \\
\hline $\begin{array}{l}\text { Program impact including } \\
\text { intrahousehold spillovers: } \\
\tau+\left(\alpha_{1}-\alpha_{2}\right)-\left(\gamma_{1}-\gamma_{2}\right)\end{array}$ & $\begin{array}{c}.0695^{*} \\
(.0360)\end{array}$ & $\begin{array}{l}.0730^{*} \\
(.0439)\end{array}$ & $\begin{array}{l}.0627 * * \\
(.0267)\end{array}$ & $\begin{array}{l}.0941 * * * \\
(.0276)\end{array}$ \\
\hline Hausman test $[p$-value $]$ & $\cdots$ & {$[.688]$} & $\ldots$ & {$[.664]$} \\
\hline Overidentification $(J$-test $)[p$-value $]$ & $\ldots$ & $\begin{array}{l}9.90 \\
{[.195]}\end{array}$ & $\ldots$ & $\begin{array}{c}12.61 \\
{[.126]}\end{array}$ \\
\hline Weak IV test ( $F$-statistic) & & 68.56 & . & 41.08 \\
\hline Observations & 9,596 & 9,596 & 9,596 & 9,596 \\
\hline$R^{2}$ & .091 & .089 & .027 & .026 \\
\hline
\end{tabular}

NoтE.-Clustered standard errors at the village level are in parentheses. Each regression includes controls for age at program introduction (ACI) at age 12 and below and at ages 13-16, age, age squared, birth order, gender, status as oldest child, mother's education, father's education, mother's education missing, and father's education missing.

* Significant at 10 percent.

** Significant at 5 percent.

*** Significant at 1 percent. 
TABLE A4

Impacts on Vocation: Marginal Effects, Multinomial Logit Estimates

\begin{tabular}{|c|c|c|c|}
\hline \multirow[b]{2}{*}{ Occupational Category } & \multicolumn{2}{|c|}{ Six Countries } & \multirow[b]{2}{*}{$\begin{array}{c}\text { MEAN } \\
\text { UNTREATED }\end{array}$} \\
\hline & $\begin{array}{c}\text { Multinomial Logit } \\
\text { Coefficients }\end{array}$ & $\begin{array}{l}\text { Marginal } \\
\text { Effects }\end{array}$ & \\
\hline 1. Agriculture & $\begin{array}{l}.532 * * \\
(.217)\end{array}$ & $\begin{array}{c}.0164 \\
(.0147)\end{array}$ & .051 \\
\hline 2. Construction, day labor & $\begin{array}{l}1.085^{* * * *} \\
(.406)\end{array}$ & $\begin{array}{l}.0147^{*} \\
(.0088)\end{array}$ & .024 \\
\hline 3. Clerical, sales & $\begin{array}{l}.623^{* *} \\
(.250)\end{array}$ & $\begin{array}{c}.0232 \\
(.0142)\end{array}$ & .050 \\
\hline 4. Blue-collar & $\begin{array}{l}.457 * * \\
(.198)\end{array}$ & $\begin{array}{l}.0141 \\
(.0110)\end{array}$ & .069 \\
\hline 5. Personal services & $\begin{array}{c}.314 \\
(.209)\end{array}$ & $\begin{array}{l}.0034 \\
(.0106)\end{array}$ & .052 \\
\hline 6. Teaching & $\begin{array}{l}.808 * * * \\
(.160)\end{array}$ & $\begin{array}{l}.0341 * * * \\
(.0120)\end{array}$ & .054 \\
\hline 7. Government & $\begin{array}{l}.897^{*} \\
(.509)\end{array}$ & $\begin{array}{l}.0059 \\
(.0048)\end{array}$ & .007 \\
\hline 8. Small business & $\begin{array}{l}.032 \\
(.144)\end{array}$ & $\begin{array}{r}-.0096 \\
(.0077)\end{array}$ & .049 \\
\hline 9. Ministry, pastoral & $\begin{array}{l}.567 \\
(.444)\end{array}$ & $\begin{array}{l}.0023 \\
(.0032)\end{array}$ & .007 \\
\hline 10. Finance and large business & $\begin{array}{l}.574 * * \\
(.268)\end{array}$ & $\begin{array}{c}.0106 \\
(.0083)\end{array}$ & .029 \\
\hline 11. Police, army, security, fire & $\begin{array}{l}.963 * * * \\
(.307)\end{array}$ & $\begin{array}{l}.0084 * * \\
(.0040)\end{array}$ & .011 \\
\hline 12. Professional, doctor, lawyer & $\begin{array}{c}-.078 \\
(.353)\end{array}$ & $\begin{array}{c}-.0052 \\
(.0049)\end{array}$ & .019 \\
\hline 13. Less skilled technical, call centers & $\begin{array}{l}.636^{* * *} \\
(.294)\end{array}$ & $\begin{array}{l}.0086 \\
(.0067)\end{array}$ & .020 \\
\hline 14. Nursing, public health, hospital & $\begin{array}{l}.505 \\
(.322)\end{array}$ & $\begin{array}{c}.0026 \\
(.0032)\end{array}$ & .011 \\
\hline
\end{tabular}

Note.-Clustered standard errors at the village level are in parentheses. Marginal effects, $d y / d x$, are from corresponding multinomial logit estimates; control variables are gender, age, age squared, birth order, oldest child, and a dummy variable for household with sponsored child. The base category is unemployment. Number of observations is 8,911 ; pseudo $R^{2}=.0470 ; \chi^{2} p<.0001$.

* Significant at 10 percent.

** Significant at 5 percent.

*** Significant at 1 percent. 
TABLE A5

OLS And IV Estimates of Equations (1), (2'), (3), And $\left(4^{\prime}\right)$ : Community Leader

\begin{tabular}{|c|c|c|c|c|}
\hline Variable & $\begin{array}{l}\text { OLS } \\
(1)\end{array}$ & $\begin{array}{l}\text { IV-GMM } \\
\text { (2) }\end{array}$ & $\begin{array}{l}\text { OLS-FE } \\
(3)\end{array}$ & $\begin{array}{l}\text { IV-GMM-FE } \\
(4)\end{array}$ \\
\hline Program participant $(\tau)$ & $\begin{array}{l}.0218 * * * \\
(.0063)\end{array}$ & $\begin{array}{l}.0007 \\
(.0149)\end{array}$ & $\begin{array}{l}.0093 * * \\
(.0041)\end{array}$ & $\begin{array}{l}-.0461^{* * *} \\
(.0133)\end{array}$ \\
\hline \multicolumn{5}{|l|}{ Compassion household: } \\
\hline $\mathrm{ACI} \leq 12\left(\alpha_{1}\right)$ & $\begin{array}{l}.0373 * \\
(.0214)\end{array}$ & $\begin{array}{l}.0501 * * * \\
(.0185)\end{array}$ & $\begin{array}{l}.0351^{* *} \\
(.0169)\end{array}$ & $\begin{array}{l}.0623 * * * \\
(.0157)\end{array}$ \\
\hline ACI $13-16\left(\alpha_{2}\right)$ & $\begin{array}{l}.0226 \\
(.0155)\end{array}$ & $\begin{array}{l}.0327 * * * \\
(.0103)\end{array}$ & $\begin{array}{l}.0230 \\
(.0146)\end{array}$ & $\begin{array}{l}.0210^{* * * *} \\
(.0076)\end{array}$ \\
\hline \multicolumn{5}{|l|}{ Program village: } \\
\hline $\mathrm{ACI} \leq 12\left(\beta_{1}\right)$ & $\begin{array}{l}.0534^{*} \\
(.0292)\end{array}$ & $\begin{array}{l}.0577 * * \\
(.0247)\end{array}$ & $\begin{array}{l}.0413 * * \\
(.0171)\end{array}$ & $\begin{array}{l}.0419 * * * \\
(.0121)\end{array}$ \\
\hline ACI $13-16\left(\beta_{2}\right)$ & $\begin{array}{l}.0567 * * \\
(.0268)\end{array}$ & $\begin{array}{l}.0736^{* * * *} \\
(.0239)\end{array}$ & $\begin{array}{l}.0493 * * \\
(.0192)\end{array}$ & $\begin{array}{l}.0474 * * * \\
(.0121)\end{array}$ \\
\hline \multicolumn{5}{|l|}{ Nonprogram village: } \\
\hline $\mathrm{ACI} \leq 12\left(\gamma_{1}\right)$ & $\begin{array}{r}-.0147 \\
(.0430)\end{array}$ & $\begin{array}{r}-.0138 \\
(.0411)\end{array}$ & $\begin{array}{l}.0121 \\
(.0201)\end{array}$ & $\begin{array}{l}.0120 \\
(.0186)\end{array}$ \\
\hline ACI $13-16\left(\gamma_{2}\right)$ & $\begin{array}{l}-.0306 \\
(.0353)\end{array}$ & $\begin{array}{r}-.0323 \\
(.0337)\end{array}$ & $\begin{array}{l}.0117 \\
(.0237)\end{array}$ & $\begin{array}{l}.0104 \\
(.0216)\end{array}$ \\
\hline \multicolumn{5}{|l|}{$F$-tests $/ \chi^{2}$ tests of parallel trends: } \\
\hline$\alpha_{2}=\beta_{2}=\gamma_{2}$ & $\begin{array}{l}2.36 \\
{[.111]}\end{array}$ & $\begin{array}{c}8.32 * * \\
{[.016]}\end{array}$ & $\begin{array}{l}1.24 \\
{[.304]}\end{array}$ & $\begin{array}{l}7.91 * * \\
{[.019]}\end{array}$ \\
\hline$\alpha_{1}=\beta_{1}=\gamma_{1}$ & $\begin{array}{l}1.39 \\
{[.263]}\end{array}$ & $\begin{array}{l}3.28 \\
{[.194]}\end{array}$ & $\begin{array}{l}.94 \\
{[.401]}\end{array}$ & $\begin{array}{c}6.42 * * \\
{[.040]}\end{array}$ \\
\hline $\begin{array}{l}\text { Intrahousehold spillovers: } \\
\qquad\left(\alpha_{1}-\alpha_{2}\right)-\left(\gamma_{1}-\gamma_{2}\right)\end{array}$ & $\begin{array}{r}-.0012 \\
(.0155)\end{array}$ & $\begin{array}{r}-.0011 \\
(.0156)\end{array}$ & $\begin{array}{c}.0118 \\
(.0197)\end{array}$ & $\begin{array}{l}.0397 * * \\
(.0186)\end{array}$ \\
\hline $\begin{array}{l}\text { Intravillage spillovers: } \\
\qquad\left(\beta_{1}-\beta_{2}\right)-\left(\gamma_{1}-\gamma_{2}\right)\end{array}$ & $\begin{array}{c}-.0191 \\
(.0242)\end{array}$ & $\begin{aligned}-.0343^{*} \\
(.0179)\end{aligned}$ & $\begin{array}{c}-.0083 \\
(.0259)\end{array}$ & $\begin{array}{c}-.0071 \\
(.0162)\end{array}$ \\
\hline \multicolumn{5}{|l|}{$\begin{array}{l}\text { Program impact including } \\
\text { intrahousehold spillovers: }\end{array}$} \\
\hline Hausman test $[p$-value $]$ & $\ldots$ & .493 & $\ldots$ & .091 \\
\hline Overidentification $(J$-test $)[p$-value $]$ & $\ldots$ & $\begin{array}{r}10.84 \\
{[.146]}\end{array}$ & $\ldots$ & $\begin{array}{l}3.03 \\
{[.933]}\end{array}$ \\
\hline Weak IV test (F-statistic) & & 61.79 & . & 40.87 \\
\hline Observations & 9,495 & 9,495 & 9,495 & 9,495 \\
\hline$R^{2}$ & .017 & .015 & .018 & .002 \\
\hline
\end{tabular}

NoTE.-Clustered standard errors at the village level are in parentheses. Each regression includes controls for age at program introduction (ACI) at age 12 and below and at ages 13-16, age, age squared, birth order, gender, status as oldest child, mother's education, father's education, mother's education missing, and father's education missing.

* Significant at 10 percent.

** Significant at 5 percent.

*** Significant at 1 percent. 
TABLE A6

OLS And IV Estimates of Equations $(1),\left(2^{\prime}\right)$, (3), And $\left(4^{\prime}\right)$ : Church Leader

\begin{tabular}{|c|c|c|c|c|}
\hline Variable & $\begin{array}{l}\text { OLS } \\
(1)\end{array}$ & $\begin{array}{l}\text { IV-GMM } \\
(2)\end{array}$ & $\begin{array}{l}\text { OLS-FE } \\
(3)\end{array}$ & $\begin{array}{l}\text { IV-GMM-FE } \\
(4)\end{array}$ \\
\hline Program participant $(\tau)$ & $\begin{array}{l}.0603 * * * \\
(.0142)\end{array}$ & $\begin{array}{c}-.0642 * \\
(.0374)\end{array}$ & $\begin{array}{l}.0352 * * * \\
(.0113)\end{array}$ & $\begin{aligned}-.0715 \\
(.0452)\end{aligned}$ \\
\hline \multicolumn{5}{|l|}{ Compassion household: } \\
\hline $\mathrm{ACI} \leq 12\left(\alpha_{1}\right)$ & $\begin{array}{r}-.0453 \\
(.0338)\end{array}$ & $\begin{array}{r}-.0109 \\
(.0198)\end{array}$ & $\begin{array}{r}-.0076 \\
(.0238)\end{array}$ & $\begin{array}{l}.0443 \\
(.0322)\end{array}$ \\
\hline ACI $13-16\left(\alpha_{2}\right)$ & $\begin{array}{r}-.0384^{*} \\
(.0223)\end{array}$ & $\begin{array}{l}-.0508^{* * * *} \\
(.0119)\end{array}$ & $\begin{array}{r}-.0113 \\
(.0198)\end{array}$ & $\begin{array}{r}-.0155 \\
(.0152)\end{array}$ \\
\hline \multicolumn{5}{|l|}{ Program village: } \\
\hline $\mathrm{ACI} \leq 12\left(\beta_{1}\right)$ & $\begin{array}{r}-.0548 \\
(.0764)\end{array}$ & $\begin{array}{c}-.0829 * \\
(.0427)\end{array}$ & $\begin{array}{r}-.0271 \\
(.0514)\end{array}$ & $\begin{array}{r}-.0148 \\
(.0377)\end{array}$ \\
\hline ACI $13-16\left(\beta_{2}\right)$ & $\begin{array}{r}-.0148 \\
(.0418)\end{array}$ & $\begin{array}{c}-.0407^{*} \\
(.0232)\end{array}$ & $\begin{array}{l}.0327 \\
(.0321)\end{array}$ & $\begin{array}{l}.0088 \\
(.0256)\end{array}$ \\
\hline \multicolumn{5}{|l|}{ Nonprogram village: } \\
\hline $\mathrm{ACI} \leq 12\left(\gamma_{1}\right)$ & $\begin{array}{r}-.0501 \\
(.0463)\end{array}$ & $\begin{array}{c}-.0680^{*} \\
(.0368)\end{array}$ & $\begin{array}{r}-.0352 \\
(.0248)\end{array}$ & $\begin{array}{r}-.0219 \\
(.0244)\end{array}$ \\
\hline ACI $13-16\left(\gamma_{2}\right)$ & $\begin{array}{r}-.0522 \\
(.0405)\end{array}$ & $\begin{array}{l}-.0669 * * \\
(.0341)\end{array}$ & $\begin{array}{r}-.0213 \\
(.0212)\end{array}$ & $\begin{aligned}-.0171 \\
(.0208)\end{aligned}$ \\
\hline \multicolumn{5}{|l|}{$F$-tests $/ \chi^{2}$ tests of parallel trends: } \\
\hline$\alpha_{2}=\beta_{2}=\gamma_{2}$ & $\begin{array}{l}.44 \\
{[.645]}\end{array}$ & $\begin{array}{l}.51 \\
{[.776]}\end{array}$ & $\begin{array}{l}1.49 \\
{[.241]}\end{array}$ & $\begin{array}{l}1.05 \\
{[.592]}\end{array}$ \\
\hline$\alpha_{1}=\beta_{1}=\gamma_{1}$ & $\begin{array}{c}.02 \\
{[.980]}\end{array}$ & $\begin{array}{c}7.57 * * \\
{[.023]}\end{array}$ & $\begin{array}{l}.77 \\
{[.470]}\end{array}$ & $\begin{array}{l}3.97 \\
{[.137]}\end{array}$ \\
\hline $\begin{array}{l}\text { Intrahousehold spillovers: } \\
\quad\left(\alpha_{1}-\alpha_{2}\right)-\left(\gamma_{1}-\gamma_{2}\right)\end{array}$ & $\begin{array}{r}-.0090 \\
(.0260)\end{array}$ & $\begin{array}{l}.0410^{*} \\
(.0242)\end{array}$ & $\begin{array}{c}.0176 \\
(.0175)\end{array}$ & $\begin{array}{l}.0647 * * \\
(.0303)\end{array}$ \\
\hline $\begin{array}{l}\text { Intravillage spillovers: } \\
\qquad\left(\beta_{1}-\beta_{2}\right)-\left(\gamma_{1}-\gamma_{2}\right)\end{array}$ & $\begin{array}{r}-.0421 \\
(.0420)\end{array}$ & $\begin{array}{r}-.0411 \\
(.0333)\end{array}$ & $\begin{array}{r}-.0459 \\
(.0321)\end{array}$ & $\begin{array}{r}-.0187 \\
(.0219)\end{array}$ \\
\hline $\begin{array}{l}\text { Program impact including } \\
\text { intrahousehold spillovers: } \\
\tau+\left(\alpha_{1}-\alpha_{2}\right)-\left(\gamma_{1}-\gamma_{2}\right)\end{array}$ & $\begin{array}{c}.0513^{*} \\
(.0266)\end{array}$ & $\begin{array}{c}-.0231 \\
(.0275)\end{array}$ & $\begin{array}{l}.0528 * * * \\
(.0191)\end{array}$ & $\begin{array}{r}-.0068 \\
(.0239)\end{array}$ \\
\hline Hausman test $[p$-value] & $\ldots$ & {$[.007]$} & $\ldots$ & {$[.144]$} \\
\hline Overidentification ( $J$-test) $[p$-value $]$ & $\ldots$ & $\begin{array}{l}4.59 \\
{[.710]}\end{array}$ & $\ldots$ & $\begin{array}{l}9.31 \\
{[.317]}\end{array}$ \\
\hline Weak IV test ( $F$-statistic) & & 63.46 & & 40.18 \\
\hline Observations & 9,468 & 9,468 & 9,468 & 9,468 \\
\hline$R^{2}$ & .018 & .001 & .005 & .056 \\
\hline
\end{tabular}

NotE.-Clustered standard errors at the village level are in parentheses. Each regression includes controls for age at program introduction (ACI) at age 12 and below and at ages 13-16, age, age squared, birth order, gender, status as oldest child, mother's education, father's education, mother's education missing, and father's education missing.

* Significant at 10 percent.

** Significant at 5 percent.

*** Significant at 1 percent. 
TABLE A7

OLS AND OLS Fixed-EFFect Estimates for EMPloyment AND LeADERShip By COUNTRY

\begin{tabular}{|c|c|c|c|c|c|c|}
\hline Variable & Uganda & Guatemala & Philippines & India & Kenya & Bolivia \\
\hline & \multicolumn{6}{|c|}{ Employed with Salary } \\
\hline \multirow[t]{2}{*}{ Program participant $(\tau)$} & .048 & $.133 * *$ & $.089 * * *$ & $.143^{* *}$ & $.039 * *$ & .025 \\
\hline & $(.031)$ & $(.045)$ & $(.011)$ & $(.040)$ & $(.015)$ & $(.040)$ \\
\hline$R^{2}$ & .192 & .137 & .136 & .313 & .049 & .134 \\
\hline \multicolumn{7}{|l|}{ Program participant $(\tau)$} \\
\hline \multirow[t]{2}{*}{ household fixed effects } & .042 & .081 & $.086^{* * * *}$ & $.145^{* *}$ & $.047 * *$ & .017 \\
\hline & $(.025)$ & $(.063)$ & $(.014)$ & $(.037)$ & $(.018)$ & $(.039)$ \\
\hline$R^{2}$ & .157 & .091 & .101 & .319 & .029 & .085 \\
\hline Observations & 798 & 1,503 & 1,341 & 1,552 & 2,942 & 1,361 \\
\hline \multirow[t]{2}{*}{ Baseline, untreated } & .544 & .281 & .425 & .646 & .136 & .353 \\
\hline & \multicolumn{6}{|c|}{ White-Collar Employment } \\
\hline \multirow[t]{2}{*}{ Program participant $(\tau)$} & .099 & $.113^{* * *}$ & $.139 * * *$ & $.065 * * *$ & $.027 * * *$ & .047 \\
\hline & $(.055)$ & $(.004)$ & $(.020)$ & $(.008)$ & $(.004)$ & $(.038)$ \\
\hline$R^{2}$ & .104 & .160 & .093 & .074 & .048 & .065 \\
\hline \multicolumn{7}{|l|}{ Program participant $(\tau)$} \\
\hline household fixed effects & .095 & $.122 * * *$ & $.128 * * *$ & $.068 * *$ & $.025 * *$ & .038 \\
\hline & $(.052)$ & $(.011)$ & $(.014)$ & $(.015)$ & $(.009)$ & $(.034)$ \\
\hline$R^{2}$ & .066 & .104 & .062 & .039 & .018 & .041 \\
\hline Observations & 809 & 1,506 & 1,376 & 1,591 & 2,942 & 1,372 \\
\hline \multirow[t]{2}{*}{ Baseline, untreated } & .184 & .182 & .298 & .362 & .056 & .149 \\
\hline & \multicolumn{6}{|c|}{ Community Leader } \\
\hline \multirow[t]{2}{*}{ Program participant $(\tau)$} & .035 & .035 & $.024 * * *$ & .016 & $.0070^{*}$ & $.023 *$ \\
\hline & $(.029)$ & $(.023)$ & $(.004)$ & $(.008)$ & $(.0035)$ & $(.010)$ \\
\hline$R^{2}$ & .101 & .036 & .026 & .037 & .019 & .072 \\
\hline \multicolumn{7}{|l|}{ Program participant $(\tau)$} \\
\hline \multirow[t]{2}{*}{ household fixed effects } & $.043^{*}$ & .009 & $-.0048^{*}$ & .005 & .001 & .021 \\
\hline & $(.018)$ & $(.009)$ & $(.0020)$ & $(.003)$ & $(.008)$ & $(.011)$ \\
\hline$R^{2}$ & .091 & .011 & .013 & .018 & .017 & .049 \\
\hline Observations & 793 & 1,487 & 1,359 & 1,543 & 2,942 & 1,371 \\
\hline \multirow[t]{2}{*}{ Baseline, untreated } & .085 & .016 & .019 & .021 & .016 & .057 \\
\hline & \multicolumn{6}{|c|}{ Church Leader } \\
\hline \multirow[t]{2}{*}{ Program participant $(\tau)$} & $.169 * * *$ & .054 & .076 & -.020 & $.063 * *$ & .027 \\
\hline & $(.032)$ & $(.040)$ & $(.038)$ & $(.012)$ & $(.020)$ & $(.028)$ \\
\hline$R^{2}$ & .080 & .071 & .054 & .036 & .021 & .037 \\
\hline \multirow{3}{*}{$\begin{array}{l}\text { Program participant }(\tau), \\
\text { household fixed effects }\end{array}$} & & & & & & \\
\hline & $.112 *$ & .015 & $.048 * *$ & .001 & $.038 * *$ & .011 \\
\hline & $(.052)$ & $(.050)$ & $(.015)$ & $(.014)$ & $(.015)$ & $(.036)$ \\
\hline$R^{2}$ & .040 & .024 & .024 & .011 & .009 & .014 \\
\hline Observations & 773 & 1,491 & 1,354 & 1,542 & 2,942 & 1,366 \\
\hline Baseline, untreated & .119 & .138 & .086 & .097 & .061 & .062 \\
\hline
\end{tabular}

NoтE.-Clustered standard errors at the village level are in parentheses. Each regression includes controls for age at program introduction (ACI) at age 12 and below and at ages 13-16, age, age squared, birth order, gender, status as oldest child, number of siblings, mother's and father's education, mother's education missing, and father's education missing. Fixed effects are at the household level.

* Significant at 10 percent.

** Significant at 5 percent.

*** Significant at 1 percent. 


\section{References}

$\rightarrow$ Aaronson, Daniel, and Bhashkar Mazumder. 2011. "The Impact of Rosenwald Schools on Black Achievement." J.P.E. 119 (5): 821-88.

Barrera-Osorio, Felipe, Marianne Bertrand, Leigh L. Linden, and Francisco PerezCalle. 2008. "Conditional Cash Transfers in Education; Design Features, Peer and Sibling Effects: Evidence from a Randomized Experiment in Colombia." Working Paper no. 13890, NBER, Cambridge, MA.

Behrman, Jere R., Susan Parker, and Petra Todd. 2007. "Do School Subsidy Programs Generate Lasting Benefits? A Five-Year Follow-up of Oportunidades Participants.” Working Paper, Univ. Pennsylvania.

$\rightarrow$ Behrman, Jere R., Piyali Sengupta, and Petra Todd. 2005. "Progressing through PROGRESA: An Impact Assessment of a School Subsidy Experiment in Rural Mexico." Econ. Development and Cultural Change 54 (1): 237-53.

Bernard, Tanguy, Stefan Dercon, and Alemayehu Seyoum Taffesse. 2011. "Beyond Fatalism: An Empirical Exploration of Self-Efficacy and Aspirations Failure in Ethiopia." Working Paper no. 2011-03, Centre Study African Economies, Oxford.

$\rightarrow$ Bertrand, Marianne, Dean Karlan, Sendhil Mullainathan, Eldar Shafir, and Jonathan Zinman. 2010. "What's Advertising Content Worth? Evidence from a Consumer Credit Marketing Field Experiment.” Q.J.E. 125 (1): 263-305.

$\rightarrow$ Bobonis, Gustavo J., and Frederico Finan. 2009. "Neighborhood Peer Effects in Secondary School Enrollment Decisions.” Rev. Econ. and Statis. 91 (4): 695-716.

Dalton, Patricio, Sayantan Ghosal, and Anandi Mani. 2010. "Poverty and Aspirations Failure: A Theoretical Framework.” Working paper, Tilburg Univ. and Univ. Warwick.

$\rightarrow$ Drèze, Jean, and Geeta Kingdon. 2001. "School Participation in Rural India." Rev. Development Econ. 5 (1): 1-24.

Duflo, Esther. 2001. "Schooling and Labor Market Consequences of School Construction in Indonesia: Evidence from an Unusual Policy Experiment." A.E.R. 91 (4): 795-813.

Duflo, Esther, Michael Kremer, and Jonathan Robinson. 2011. "Nudging Farmers to Use Fertilizer: Theory and Experimental Evidence from Kenya." A.E.R. 101 (6): 2350-90.

Dupas, Pascaline. 2010. "Short-Run Subsidies and Long-Run Adoption of New Health Products: Evidence from a Field Experiment." Working Paper no. 16298, NBER, Cambridge, MA.

Evans, David, Michael Kremer, and Mũthoni Ngatia. 2008. "The Impact of Distributing School Uniforms on Children's Education in Kenya." Working paper, World Bank, Washington, DC.

Furth, Gregg. 2002. The Secret World of Drawings: A Jungian Approach to Health through Art. Toronto: Inner City Books.

$\rightarrow$ Glewwe, Paul, Nauman Ilias, and Michael Kremer. 2010. "Teacher Incentives." American Econ. J.: Appl. Econ. 2 (3): 205-27.

Glewwe, Paul, and Edward Miguel. 2008. "The Impact of Child Health and Nutrition on Education in Less Developed Countries." In Handbook of Development Economics, vol. 4, edited by T. Paul Schultz and John A. Strauss. Amsterdam: North-Holland.

Glewwe, Paul, and Bruce Wydick. 2013. "Child Sponsorship and Child Psychology: Evidence from Children's Drawings in Indonesia.” Working paper, Univ. San Francisco.

Handa, Sudhanshu, and Amber Peterman. 2007. "Child Health and School Attainment: A Replication.” J. Human Resources 42 (4): 863-80. 
Kennedy, John. 2009. "The Not-for-Profit Surge.” Christianity Today 53 (5): 22-27.

Klepsch, Marvin, and Laura Logie. 1982. Children Draw and Tell: An Introduction to the Projective Uses of Children's Human Figure Drawings. New York: BrunnerRoutledge.

Koppitz, Elizabeth. 1968. Psychological Evaluation of Children's Human Figure Drawings. New York: Grune \& Stratton.

$\rightarrow$ Kremer, Michael, Edward Miguel, and Rebecca Thornton. 2009. "Incentives to Learn." Rev. Econ. and Statis. 91 (3): 437-56.

Kremer, Michael, Sylvie Moulin, and Robert Namunyu. 2003. "Decentralization: A Cautionary Tale." Working paper no. 10, Poverty Action Lab, Cambridge, MA.

Kremer, Michael, and Christel Vermeersch. 2004. "School Meals, Educational Attainment, and School Competition: Evidence from a Randomized Evaluation." Policy Research Paper no. 3523, World Bank, Washington, DC.

$\rightarrow$ Miguel, Edward, and Michael Kremer. 2004. "Worms: Identifying Impacts on Education and Health in the Presence of Treatment Externalities." Econometrica 72 (1): 159-217.

Mullainathan, Sendhil. 2006. "Development Economics through the Lens of Psychology." Working paper, Harvard Univ.

Office of Management and Budget. 2012. Fiscal Year 2012 Budget of the U.S. Government. Washington, DC: Office Management and Budget.

Ozier, Owen. 2011. "Exploiting Externalities to Estimate the Long-Term Effects of Early Childhood Deworming." Working paper, World Bank, Washington, DC.

$\rightarrow$ Pitt, Mark, Mark Rosenzweig, and Donna Gibbons. 1993. "The Determinants and Consequences of the Placement of Government Programs in Indonesia." World Bank Econ. Rev. 7 (3): 319-48.

Ray, Debraj. 2006. "Aspirations, Poverty, and Economic Change.” In Understanding Poverty, edited by Abhijit Vinayak Banerjee, Roland Benabou, and Dilip Mookherjee. New York: Oxford Univ. Press.

Ross, Phillip. 2010. "An Investigation of Reference Point Shifts from a Child Sponsorship Program in Bolivia." Working paper, Univ. San Francisco.

Ross, Phillip, and Bruce Wydick. 2011. "The Impact of Child Sponsorship on Self-Esteem, Life-Expectations, and Reference Points: Evidence from Kenya." Working paper, Univ. San Francisco.

$\rightarrow$ Schultz, T. Paul. 2004. "School Subsidies for the Poor: Evaluating the Mexican Progresa Poverty Program.” J. Development Econ. 74:199-250.

World Bank. 2009. Conditional Cash Transfers: Reducing Present and Future Poverty. Policy Research Report. Washington, DC: World Bank.

Wydick, Bruce, Paul Glewwe, and Laine Rutledge. 2013. "Does Child Sponsorship Work? Evidence from a Six-Country Study on Adult Life Outcomes." Working paper, Univ. San Francisco. 